\title{
Türkiye Ekonomisi Üzerine: İktisadi Bir Konu Mu, Uluslararası İlişkilerin Dinamik Ekonomi Politiği Mi?
}

\author{
Mahir Terzia ${ }^{a}$, Asskın İnci Sökmen Alacac
}

\section{Özet}

Türkiye ekonomisinin 2019 Ekim itibariyle içinde bulunduğu mevcut durum, iktisat disiplininin kendi parametreleri dikkate alınarak açıklanabilecek niteliktedir. Politik ekonominin aktörleri de nihayetinde bu parametreleri kullanarak Türkiye ekonomisinin kırılganlığg üzerinden hareket etmektedir. Ülke ekonomisinin geleceği için dış yatırımların cazip hale getirilmesi, ara malı üretilmesi ile Endüstri 4.0 ve 5.0 dâhil olmak üzere bilgi ve iletişim teknolojilerinde uzmanlaşmanın hedeflenmesi gerekmektedir. Mevcut veriler, Türkiye'nin komşularıyla barış içerisinde olmasını, mevcut demokrasisinin daha da demokratikleştirilmesini, adalet mekanizmasının geliştirilmesini, eğitime ve insan kaynağına önem verilmesini, kritik öneme sahip unsurlar olarak ortaya koymaktadır.
Anahtar Kelimeler

Türkiye Ekonomisi

Siyasi Liberalizm

Uluslararası İlişkilerin Ekonomi Politiği

Makale Hakkında

Geliş Tarihi: 31.03.2019

Kabul Tarihi: 24.04.2020

Doi: 10.18026/cbayarsos.547324

\section{On the Economy of Turkey: Is It the Economical Subject Matter or Is It the Dynamic Political Economy of International Relations?}

\begin{abstract}
As of October 2019, the current situation in Turkey's economy can be explained by taking the parameters of the discipline of economics itself into account. By finally using these parameters, the actors of political economy move over the fragility of the economy of Turkey. For the future of the country's economy, it is necessary to make foreign investments attractive, to produce intermediate goods and to be specialized in information and communication technologies including Industry 4.0 and 5.0. Available data show that Turkey's being in peace with her neighbors, democratization of the existing democracy, the promotion of justice mechanisms, giving importance to the education and human resources are elements which have critical importance.
\end{abstract}

Keywords

The Economy of Turkey

Political Liberalism

Political Economy of International Relations

About Article

Received: 31.03.2019

Accepted: 24.04 .2020

Doi: 10.18026/cbayarsos.547324

a İletişim Yazarı: mahirterzi@yahoo.com.

b Dr., Kültür ve Turizm Bakanlığı, ORCID: 0000-0003-1308-2060.

c Doç. Dr., İstanbul Arel Üniversitesi, ORCID: 0000-0002-2021-137X. 


\section{Giriş}

Türkiye ekonomisinin başarısız göstergelerine (büyüme oranı, enflasyon, bütçe açı̆̆ı, cari açık vb.) yönelik iki temel yaklaşım gözlemlenmektedir. Bunlardan ilki, Türkiye'nin ekonomisini, iktisat disiplininin kendi içindeki değişkenlerle yani mikro ve makro parametrelerle açıklama eğilimindedir. Diğeri ise politik ekonomi çerçevesinde açıklamakta ve dışsal faktörlere ağırlık vermektedir. Trump' 1 “...Will devastate Turkey economically if they hit Kurds... (...Eğer Kürtleri vururlarsa, Türkleri ekonomik olarak mahvedeceğiz...)” (Sullivan and Stark, 2019) ifadesi, bu bakış açısını daha da kuvvetlendirmektedir.

Haliyle çalışmanın amacı, mevcut her iki bakış açısının da Türkiye ekonomisinin gidişatına etki ettiğini göstermektedir. Ancak ağırlığı, iktisat disiplininin kendi parametlerine vermek yerinde olacaktır; çünkü dış politikanın aktörleri, Türkiye'yi hedef aldığında bunu ekonominin kendi parametreleriyle (döviz, tarifeler vb.) gerçekleştirmeye çalışmaktadır.

Çalışmanın önemi, Türkiye ekonomisinin gidişatının Türkiye'nin komşularıyla barış içerisinde olması, demokrasi, insan hakları ve hukuku geliştirmesi, eğitime ve insan kaynağına önem vermesi gerektiğini kısaca ekonominin bu değişkenlerle yani mikro ve makro ekonominin ilişkili olduğu diğer parametrelerin gerekliliğini hatırlatmaktır. Açıktır ki siyasal liberalizmi dikkate almadan sadece ekonomik liberalizm ile iyi bir performans sergilemek mümkün olmayacaktır.

Çalışmada disiplinler arası bir yaklaşım sergilenmiş olup, betimsel-istatistiksel yöntem kullanılmıştır. Mevcut teori ve yaklaşımlar dikkate alındığında, yapılan değerlendirmeler, tümdengelimci bir yaklaşımla ele alınmıştır. Çalışmanın nihai amacı, tüm parametreleri dikkate alıp Türkiye ekonomisi üzerine kapsamlı bir kitap yazmak olmadığından, çalışmanın sınırını peşinen söylemek gerekirse, Türkiye ekonomisinin geleceğine ilişkin yapısal nitelikte görülen hususlar yani ara malı üretimi-imalat sanayi, tasarruf-dış yatırım ile hizmet sektörübilgi ve iletişim teknolojileri (Endüstri 4.0 ve Endüstri 5.0 dâhil) oluşturmaktadır. Bir diğer sınır ise politik ekonomik çerçevedir.

Varılan sonuçlar açısından; çalışmanın önemi ile sonuçlarının örtüştüğünü söylemek mümkündür. Barış, demokrasi, insan hakları, hukukun üstünlüğü, eğitim, insan kaynağına yatırım ve inovasyon ile Türkiye ekonomisinin yapısal sorunlarına odaklanmak, Türkiye'nin ekonomik geleceği için önemlidir. ${ }^{1}$ Her ne kadar Çin'in başarısı ve dünyadaki son gelişmeler, liberalizm için "out" tartışmalarını tetiklese de siyasal liberalizm önemini korumaktadır. ${ }^{2}$

\section{Dünya Ekonomisinin Genel Durumu}

Soğuk Savaş'ın 1991 yılında, Sovyetler Birliği'nin ekonomik olarak çökmesiyle ve ABD önderliğindeki Batı dünyasının zaferi ile sonuçlanmasıyla, Kapitalizme dayalı neoliberal düzen, tüm dünya ülkeleri için benimsenmesi gereken bir ekonomik sistem olduğunu ilan etti. Kapitalist neo liberal ekonomik düzen, ülkeler arasında hiyerarşik bir yapı ortaya çıkarmaktadır. Liderlik mücadelesi günümüzde ABD ile Çin arasında devam etmektedir. 
Sistemin kendisinin serbest piyasa üstünlüğüne dayanan, yoğun kontrolsüz finansal serbestleşme ve finansal piyasaların reel üretim sektörlerinin önüne geçtiği, zenginliği sayısı oldukça az belli bir kesimin elinde toplamasına imkân sağlayarak gelir dağılımını bozan, bölgesel ve ülke içi eşitsizliği arttıran, bir toplumsal ve ekonomik yapı ortaya çıkarması ve küresel mali ekonomik krizler³, hükümet krizleri, iç ayaklanmalar ve hatta 1rkçllık ve yabancı düşmanlığını arttırarak savaşlarla sonuçlanabilme özelliği bulunmaktadır.

Üretimin daralması, ticaretin gerilemesi, bütçe açıkları, giderek büyüyen devlet borçları, ülkeler arası ve ülke içi gelir dağılımı eşitsizlikleri ve büyüme-istihdam ilişkisinin bozulması sonucu artan işsizlik, kapitalist sistem yerine yeni bir sistem ihtiyacını doğurmaktadır. Yeni sistem ihtiyacının birçok nedeni bulunmaktadır. Karl Marx'ın (1867/2004) Emek-Değer teorisinde ortaya koyduğu aşırı üretim/eksik tüketimden kaynaklanan sistemin yapısının kriz doğuran özelliği, uluslararası ekonomik ve siyasi sisteme yön veren lider ülkenin kendi çıarlarını ön planda tutan uygulamaları, doğrudan yabancı yatırımlara bağımlı ülke ilişkileri, soruna sebep olan faktörler üzerinden soruna çare bulma çabaları, emek koşullarının iyileştirilmesinden çok kredi ve borç genişlemesinin derinleşmesi, krizlerin maliyetini yüksek vergilere sahip emek ücretlerindeki düşüşle ödenmeye çalışılması ve tüketimin daha da düşmesi söylenebilir. Krizlere çözüm için öncelikle çalışanların maaşlarının düşürülmesi, emeklilik sürelerini uzatma, işsizlik ödemelerinin düşürülmesi, bu kesimler üzerinde gelecek ve güvence kaybına neden olmaktadır. Böyle bir ekonomik yapı popülist politikaların artmasını sağlarken, yabancı ve göçmen karşıtlığı hatta bazı ülkelerde ırkçı eğilimlerin güçlenmesine neden olmuştur. Özellikle Almanya tarafından ortaya atılmış olan üretimde robotlara dayanan "Sanayi 4.0" sistemi, teknolojik gelişme sonucu birçok sektörde insan gücüne dayalı işlerin sonunu getirecektir. Küresel iklim değişikliği de gida üretimi üzerinde olumsuz etkiler yaratmaktadır. Toplumsal ve siyasal hareketleri ${ }^{4}$ de beraberinde getiren bu süreçte ülkelerin istikrarını sağlayabilmeleri güçleşmektedir.

Finans odaklı büyüme stratejilerinin, meta üretim ve ticaretin yerini aldığı bu sistemin birçok ülkede sorunlara yol açmasında yapısal özellikler dışında, ekonomik açıdan lider ülkenin, kendi üstün politik ve ekonomik gücünü sürekli muhafaza edecek, kendi çıkarlarına göre yönetmek istediği küresel politikaları yer almaktadır. Suzan Strange'in (1988: 25) "Yapısal güç" kavramı çerçevesinde bu sistem II. Dünya savaşından sonra IMF, Dünya Bankası (DB) ve Amerikan hazinesi, para birimi dolar temeline göre oluşturuldu. Washington Uzlaşısı ${ }^{5}$ olarak adlandırılan finansal ve ticari yapısı, devleti bir kenara iten piyasayı tek seçici olarak öngören ve sağlam para esasına dayanmaktaydı. ABD Kongresi ve Beyaz Saray'ın oluşturduğu politik yapı, kendi kurdukları finansal kurumlar ülkeleri kendilerine bağımlı kılarak, dış politikasında kendi çıkarlarını uygulatmak istediği ülkelere karşı havuç/sopa mantığına dönüşmüştür. Ortaya çıkan krizler özellikle 1997 Asya krizi Japon ekonomisinin ABD'yi geçmeye yakın olduğu dönemde çıkmış, 2008 ekonomik krizi aynı özelliklere sahip Alman ekonomisini vurmuştur. ABD'nin uluslararası finans yapısına olumsuz etkileri, 1980 yıllarında Başkan Reagan döneminde başlamıştır. Aşırı askeri yayılma ve büyüyen kamu borçları, bütçe açıklarını arttırmış, faiz oranlarını ve doların değerini yükselterek, Amerikan üreticilerinin rekabet gücünü düşürmüştür. Amerikan ekonomisinde finansal yapı üretim endüstrisinin yerini almış ve ekonominin itici gücü olmuştur. 1970'lerde dolar dalgalandığ zaman, Japonya ve Almanya ticaret fazlası verirken, Amerikan ekonomisi ticaret açı̆̆ vermiştir. Ekonomisinin liderlik gücünü aşırı askeri harcamalara ve finansal spekülasyonlara 
harcadığı için Amerika'nın liderliğindeki dünya ekonomisi güven arz etmemektedir (Ping, 2009: 47).

Liderliği kimseye kaptırmak istemeyen ABD'nin kriz çıkarma potansiyeline sahip olması büyük bir güvensizlik yaratmıştır. Para değerini zayıflatmak istediği ülkelere yönelik döviz manipülasyonları (Behnke, 2006), kendi başına ambargo koyduğu İran ile işbirliği yapan ülkelere kestiği cezalar (Swaine, 2018), Suudi Arabistan'ı ikna ederek petrol fiyatını düşürerek Rusya ekonomisini daraltması (BBC, 2016) Trans Atlantik anlaşmasının uygulanmaması için Alman otomotiv firmalarının lobi faaliyetleri sonrası Alman otomobil markalarını ulusal güvenliği açısından tehdit görmesi (Donahue, 2019), Orta Doğu'da yaptığ1 müdahaleler sonrası kendi petrol şirketlerinin çıkarlarına göre bir kontrol sistemi kurması (Hinchliffe, 2016) gibi bu sistemin liderinin göreceli kazançları mutlak kazançlara yeğlediğini göstermektedir.

\section{Küresel Ekonomik Alanda Çin-ABD Mücadelesi}

ABD'nin son dönemde kaos çıkarma eylemlerinin asıl nedeni Çin ekonomisinin büyük bir güç kazanması, elde ettiği bu ekonomik gücü jeoekonomik amaçlı kullanarak yapısal güce uygun alternatif bir ekonomi bloğu oluşturmasıdır. Washington Uzlaşısı'na karşın, kalkınma da Joshua Cooper Roma (2004) tarafından adlandırılan Pekin Uzlaşısı önem kazanmıştır. 1 Ekim 1949 yılında Marksist-Leninist ideolojiye dayalı kurulan Çin Halk Cumhuriyeti, kurucu lideri Mao Zedung ölümüyle ekonomide dışa açılma politikası izleme kararı almıştır. 1979 yılında Deng Xiapoing'in politikaları günümüz ekonomik devinin yaratılmasını sağlamıştır. Dünyanın en büyük nüfusu, ucuz işgücü imkânı yarattığından, en fazla doğrudan yabancı yatırımını çeken ülkelerin başını oluşturmuştur. Kıyıda yer alan beş eyalet ile başlayan serbest bölgeler tüm ülke geneline yayılmıştır. Yabancı yatırımların bir kısmını Hong Kong ve Tayvan'dan gelen emek yoğun endüstri oluşturmuş ve aynı zamanda piyasa tecrübesi, teknoloji ve ticari deneyim de transfer edilmiştir. Orta sınıfa geçen insan sayısı ile yoksullukla mücadelede belli bir başarı elde eden ülke, kalkınma modeli ile de diğer gelişmekte olan ülkelere örnek olmuştur. Amerikan menşeili kurumların Doğu Avrupa ve eski Sovyet ülkelerinde 1990'larda "Şok Terapi" olarak adlandırılan ekonomik reform paketini uygulamayarak, kendi kararlarını, arkasında büyük bir halk desteği ile hayata geçirmiştir. Devletin piyasadaki rolü etkin kalarak bu kalkınma modeli gerçekleşmiştir. Özelleştirme yapmamışlardır. İlk, tarıma dayalı bir kalkınma modeli uygulamışlar sonrasında endüstriye geçmişlerdir. Pekin Uzlaşısının on ilkesi kısaca yerel kalkınmaya önem verme, planlamaya dayalı Pazar, Hong Kong ve Macau için tek bir ülke farklı iki sistem gibi belli konularda esneklik sağlama, Çin özelliklerine dayalı bir model olması, tek partiye dayalı istikrarlı bir siyasi ortam, kendi kendine yeterli olma, sanayileşmeyi sürekli geliştirme ${ }^{6}$ inovasyon, hızlı değil ama dikkatli bir finansal liberalleşme ve halkın sosyal ve kültürel değerlerini kaybetmeden ekonomik büyümenin gerçeklemesidir. Pekin Uzlaşısı böylece demokrasinin olmadığ 1 bir piyasa reformu ya da Çin özelliklerine dayanan Sosyalist piyasa ekonomisi olarak tanımlanabilir. (Li, Brodsgaard ve Jacobsen, 2009: 201-308)

Sanayileşmesini finanse etmek için Latin Amerika ülkeleri özellikle Brezilya, Arjantin ve Meksika uluslararası kredi kurumlarından kısa vadeli borçlanıp, yüksek faiz oranlarını uygulayan ABD ve Avrupa yüzünden 1980-90 yılları arasında borç krizine sokulmuştu. 1997 
Asya finans krizi, 1998 Rusya finansal krizi ve 2008 dünya ekonomik krizi, Çin modeli kalkınma modelini alternatif bir model olarak ortaya çıkardı. Vietnam, Laos, Hindistan, Rusya, İran, Brezilya, Zimbabwe ülkelerinin liderleri Pekin Uzlaşısına ilgi göstermiştir. (Huang ve Ding, 2006: 29)

Hegemonya kurmak istemediğini ileri süren, sürekli barışçll bir yükselme içinde olduğunu vurgulayan Çin, devletçi kapitalizmin, devletin asla karışmadığı serbest piyasa modeline göre daha istikrarlı sonuçlar doğurmuştur. Soğuk Savaş döneminde 1955'de Baldung Konferansı'na eşlik eden Çin için gelişmekte olan ülkelerin kalkınması büyük önem taşımaktadır. Yoksullukla mücadele konusunda, kendi Pekin modeli, bu ülkeler açısından izlenebilecek bir model olarak düşünülebilmektedir.

Çin'in ekonomik büyümesinin uluslararası gücü ve etkisini küresel liderlik sağlayabileceğini düşündügü bir noktaya taşımıştır. Çin'in küresel ekonomik sistem ile ilgili endişeleri; özellikle G20, Uluslararası Para Fonu (IMF) ve Dünya Ticaret Örgütü (DTÖ) özelinde uluslararası kuruluşlar ve bunların ilgili kural ve pratikleri ve ABD ile ticari dengesizlikler ve kur farklılıkları konularındaki ikili ilişkileridir. Her zaman uluslararası ekonominin adil, istikrarlı ve sürdürülebilir olmasına dikkat çeken Çin, IMF ve DB'ye alternatif olarak Asya Altyapı Yatırım Bankası ile yeni yatırım bankasını kurmuştur. 1997-1998 Asya mali krizinde, para birimini devalüe etmemesi, Çin'in bu alandaki politikalarının sorumlu büyük bir güç olduğunu göstermektedir (Harris, 2014: 133). "Sorumlu süper güç" kavramı çerçevesinde gösterilen Çin'in dünya ekonomisinde üstlendiği liderlik rolü, en yüksek büyüme oranına sahip olmasından kaynaklanmaktadır. Yaklaşık yüzde 6-7 arası büyüme oranı, kapitalist sistemin lokomotifi olmasını kolaylaştırmıştır. Büyümeyi sağlayan ticaret ve yatırımlar, üretimdir. Dünya ekonomisinde küreselleşmenin liderliğini üstlenmiş Çin, yükselen ekonomiler (E-7) olarak adlandırılan (Hindistan, Brezilya, Rusya, Endonezya, Meksika ve Türkiye) ve BRICS ile özdeşleştirilen alternatif bloğun lideridir.

BRICS ülkeleri terimi ilk olarak Goldman Sachs'ın baş ekonomisti Jim O'Neill tarafından, 30 Kasım 2001 yılında yazdığı makalede değinerek literatüre sokulmuştur. O'Neill “Geniş coğrafyalara hükmeden, büyük kaynakları bulunan bu beş ülkenin dünya ekonomisinde giderek büyüyen bir pay sahibi olacağını, dolayısıyla ekonomiye yön verilmesinde onlara daha fazla söz hakkı tanınması gerekmekte" olduğunu belirtmişti (O'Neill, 2001: 3). Ekonomi çevrelerinde zaten tartışılmakta olan bu yeni eğilim, Amerikan akademisyenlerince gelişmekte olan bölgeler ya da yükselen pazarlar olarak ifade edilen Asya Bölgesi için Goldman Sachs'ın 'BRICS' kısaltması ile isim arayışı çözümlenmiştir. O'Neill'in ön gördüğü gibi bu ülkeler, 2001 yılından itibaren GSYH artışları açısından dünyanın en hızlı büyüyen ekonomileri arasında yer almışlardır. BRICS için inanılan bir diğer inanışta yeni bir dünya ekonomik düzeni yaratacaklarına duyulan inançtı. Özellikle Çin'in çift haneli rakamlara ulaşarak dünyanın en büyük ikinci ekonomisi haline gelmesi BRICS' de önemli rol oynamasına etkin olmuştur. BRICS ülkeleri, Birleşmiş Milletler (BM) çatısı altında siyasi ve güvenlik yönetişim yapısını ve uluslararası mali, parasal ve ticaret sistemlerini yeniden biçimlendirecek ve daha fazla etkiye sahip olacak yeni bir işbirliği mekanizması oluşturmuşlardır.

Çok kutuplu ekonomik yapıda "güç dengesi@ neredeyse büyük güçler arasında birer strateji haline gelmiştir. $A B$ için Rusya ve ABD'ye karşı Çin, Çin için $A B D^{\prime}$ ye karşı Rusya ve $A B$ önem 
kazanmıştır. ABD dışında diğer tüm büyük güçler, çok taraflı işbirliği mekanizmasından yanadır. İngiltere kendisini artık Avrupa kimliğinden sıyırarak, küresel bir aktör olmayı hedeflemiş ve ulusal çıkarı için Çin ile ekonomik işbirliğini en önemli gündem maddesi haline getirmiştir. ABD’ne rağmen Asya Altyapı Yatırım Bankası'nın -08 Ekim 2019 tarihi itibariyle100 onaylı üyesi arasında yer alan Avrupa ülkeleri, ekonomik konularda Çin etrafında yer almaktadırlar. Bankaya en çok katkı sağlayan 10 ülkenin içerisinde Almanya-Fransa-İngiltere yer almaktadır (Asian Infrastructure Investment Bank, 2019).

Jeoekonomiyi en iyi uygulayan bir devlet olarak, tarihsel ipek yolunu yeniden "Bir Yol Bir Kuşak" projesi kapsamında hayata geçirerek, "Afro Avrasya" adı verilen bir alanı, dünyanın yeni ekonomik bölgesi haline getirmeyi planlamaktadır. Afrika, Asya, Doğu Avrupa ve Avrasya bölgesi ile birlikte Ortadoğu'nun bir bölümünün dâhil olduğu bu bölge, ekonomik gücün Batıdan Doğuya doğru kayması ile birlikte önem kazanmış ve bu bölgedeki jeoekonomik istikrar ve güç mücadelelerinin ortaya çıkmasına neden olmuştur. Afro Avrasya bölgesinde yer alan tüm Avrupa ve AB de Kuzey Amerika dışında kalan bölgeyle revizyonist projeye eklenmektedir (Uhlig, 2009. )

Küresel yönetişimi, tek taraflı hareket etmeye tercih eden Çin için İpek Yolu Kuşağı projesi ile küresel yönetişim sisteminde bir dönüşüm başlayacaktır. Karşılıklı bağımlılık yanında küresel yönetişimde ortak hareket etmek AB-Çin ilişkilerinin belirleyici unsurlarındandır. Ancak BM Güvenlik Konseyi, IMF ve Dünya Bankasındaki orantısız adil olmayan temsil haklarından Avrupa'nın lider ülkeleri vazgeçmek istememektedir. Küresel yönetişimde belirleyici olan yine üçüncü ülke ABD olmakta, birçok uluslararası antlaşmaya taraf olmadığı için AB, Çin ile çevre konularında ortak hareket etmeye devam etmektedir. G-20, Çin'in G7'ye karşı tercih ettiği küresel platformdur. Bunda BRICS ülkelerinin de dâhil olmasını özellikle Rusya'nın dâhil olmasını istediği için küresel ekonomik yönetişim alanında G20, tercih edilen platform olmuştur. BM Güvenlik Konseyi'ne Almanya'nın da alınmasına Çin olumlu bakmaktadır. Beraber hareket edebildiği iyi anlaştığı ülkeleri küresel yönetişime davet ederek sayıca çoğunluk oluşturmayı hedeflemektedir.

Çin, küresel düzende Batının rolünün politik merkez, ekonomik liderlik ve kural koyuculuk konusunda azaldığını ve bu boşluğun Asya tarafından doldurulduğunu sıklıkla dile getirmektedir ayrıca Avrupa'nın ve Amerika'nın tarih sahnesindeki üstünlüklerini geçici olarak görmektedirler. Çinliler kendi medeniyetlerini her zaman dünyanın merkezi olarak ifade etmişler ve bu nedenle Çinliler kendi ülkelerini Çincede 'Zhongguo' yani 'merkez ülke/krallık' olarak adlandırırlar (Göncü, 2017). “Doğu yükseliyor, Batı düşüyor” ve “Güney yükseliyor, Kuzey düşüyor" ifadeleriyle anlatılan bu durum, dünyanın ekonomik ve siyasi merkezinin Avrupa-Atlantik'ten Asya-Pasifike kaydığını göstermektedir (Ikenberry, 2008). Bu sürece neden olan iki kriz 1997 Asya Krizi ve 2008 finansal krizi, küresel ekonomik sistemin yenilenme ihtiyacını doğurmuştur. Her krizi fırsata çeviren Çin, sorumlu bir güç olarak Asya bölgesine yardım etmiş, Avrupa' da parasal imkân sağlamıştır. IMF gelişmekte olan ülkeleri de oylama sistemine dâhil etmiş, yuanı özel çekme haklarına eklemiştir. Halen ABD liderliğinde küresel düzen ve yönetişim devam etse de, Amerika sorunları çözmek yerine bizzat sorun yaratmaya devam etmektedir. Terörizmle mücadele, korumacılık, küreselleşme karşıtlı̆̆ı, popülizmin yükselişi, küresel yönetişimin çözüm üretmedeki yetersizliği, AB 
entegrasyonunu zayıflatan Brexit süreci, göç problemleri, AB-ABD arasındaki ticaret, iklim konularındaki görüş ayrılıkları örnek olarak verilebilir.

\section{Küresel Ekonomide AB-ABD İlişkileri}

$A B$ ve $A B D$ çok yakın müttefik ve ticaret ortağı yaklaşımı, korumacılık politikaları ve müttefiklik kavramını artık benimsemeyen ABD tarafından zayıflatılmıştır. Özellikle Trump yönetimi ticaret açığı verdiği $\mathrm{AB}$ ekonomik ilişkilerinde ilave vergilere koyarak kendini koruma altına almış, 2008 finansal krizine neden olarak Euro bölgesinde halen devam eden krizle, düşük büyüme oranına sahip bir $A B$ yaratmıştır. Avrupa içerisinde aşırı sağ ve popülist eğilimlere örtülü destek, ortak karar alamayan $\mathrm{AB}^{\prime}$ yi kilitlemiştir. İzlenen tüm politik faaliyetler, dost ülkeden çok rakip ülke görülerek, $A B^{\prime}$ nin stratejik aktör vasfını yitirmesine neden olmuştur. ABD bırakacağı boşluğu zaten güçlü bir zemine sahip Çin dolduracaktır. Rusya ile de enerji bağımlılığı hatta savunma güvenlik alanlarında destek alarak, ilişkiler, belirli Avrupa ülkeleriyle devam ettirilecektir. Almanya-Rusya arasında Kuzey Akım 2 doğal gaz projesi, Fransa'nın silah satışları, otoriter rejimler olarak Macaristan, Polonya ve Sırbistan'dan yakın ilgi gösterilmesi bu görüşe örnek verilebilir.

Dünya da liberal değerlerin gerilemesi, otoriter eğilimlerin artması, popülist ve milliyetçi görüşlerin yaygınlaşması, Rusya ve Çin gibi rejimlerin eleştirilmesini zayıflatmıştır. AB bizzat kendi liberal değerleri ile çelişen bir örgüt konumuna gelmiştir. Orta Avrupa üyeleri eski bağlılıklarına daha fazla değer vermekte, $A B$ kararlarına özellikle göç ve kemer sıkma politikalarına karşı çıkmaktadırlar. ABD ve İngiltere tarafından terk edilmek üzere olan Avrupa, milliyetçi ve kimlik politikalarını öne çıkaran gruplar tarafından ulus devlet yapıları zayıflatılmaya başlamıştır. Bölünmenin derinleştiği AB'nin devamlılığı konusunda olumsuz görüşler artmıştır. Örgüt ortadan kalktığında Çin-Fransa-Rusya-Almanya arasında diğer ülkeler üzerinde büyük bir nüfuz mücadelesi başlayabilir. ABD ve İngiltere daha çok Doğu Asya ve Pasifik'te Çin ve Rusya ile karşı karşıya geleceklerdir.

$\mathrm{Bu}$ yeni düzen yaratılırken Türkiye neresinde olacak sorusu, önem kazanmaktadır. Özelleştirme olmadan, serbest ticaret bölgeleri yaratılarak kendi kendine yeterli bir ülke haline gelinebilir mi... Türkiye'nin jeopolitik konumu, dış politikasında ticari devlet ${ }^{7}$ stratejisini izleyerek ve özellikle Ekonomik Türk Diaspora kavramına yoğunlaşarak başarılı olmasını sağlayabilir mi... Projeksiyonlar çoğaltılabilir. Ama bunlardan önce Türkiye ekonomisinin kendi yapısal sorunlarını çözmesi gerekmektedir.

\section{Türkiye Ekonomisinin Genel Durumu}

Herhangi bir ülke ekonomisine ilişkin karşıt ve hırçın tartışmaların temelinde, iktisat disiplininin ontolojik niteliğinin yattığını söylemek abartılı olmayacaktır. Bir konuyu incelemede belirlenen değişkenlerin sayısındaki bir artış ve/veya eksiliş, varılacak sonucu değiştirecektir. İktisat tarihi ve iktisat teorisi, aynı zamanda bu değişkenlerin ve bu değişkenlerin yer aldığı koşulların tarihidir. 
Daha önceki tarihlerde gerçekleşen istatistiki verilere ve bu verilere göre oluşturulan iktisat teorilerine dayanarak, gelecek için perspektifler belirlemeye çalışmak da daha önce gözlemlenmeyen değişkenlerin ve koşulların devreye girmesiyle yanıltıcı olacağ1 gibi, bu yanılma aynı zamanda yeni istatistiki verilerle, yeni teorileştirme sürecinin de başlangıcı olacaktır. Kısacası, iktisat, işler iyi gittiğinde, her şey yolunda deyip dikkatleri başka alanlara çevirip, (örneğin) aradan 5 yıl geçtikten sonra tekrar, nerede kalmıştık deyip, takibe devam edilecek bir husus olmayıp, piyasanın sürekli olarak etki-tepki çerçevesinde aralıksız izlenmesini gerektiren oldukça dinamik bir disiplindir.

Haliyle Türkiye ekonomisinin geleceğine ilişkin perspektifler de disiplinin bu dinamik yapısından dolayı, ister istemez hırçın tartışmaların konusu olabilmektedir. Öyle ki ilk bakışta ülke ekonomisi için olumsuz olarak görülebilecek doların Türk lirası karşısındaki değeri; ithalatı azaltacağı ve böylece cari açığın daha azalacağı düşüncesiyle, doların Türk lirası karşısında biraz daha değer kazanması istenebilmektedir. Diğer bir ifadeyle örneğin 18 Aralık 2018 itibariyle 5,40 TL düzeylerinde olan 1 \$'ın biraz daha artması, ithalatı daha da azaltacağ1 düşüncesiyle, cari açığı düşürecektir diye savunulabilir. ${ }^{8}$ Öte taraftan, Türkiye'de üretimin yaklaşık yüzde $60^{\prime} ı$, yüzde $70^{\prime} i$, ara malları ve sermaye malları açısından ithalata bağlı olduğundan, döviz kurunun artması, ithal mallarının maliyetini artıracağından, üretimin azalmasına ve böylece ülke ekonomisinin küçülmesine neden olacağ ${ }^{1}$ da ileri sürülebilir. ${ }^{9}$ Haliyle istenen amaca ve sahip olunan yeteneğe göre ekonomik bir performans sergileneceği ortadadir.

Hırçın tartışmalarda diğer bir husus ise kullanılan verilerin hangi bağlamda kullanıldığıdır. Örneğin Türkiye'nin dış borç stoku, gelişmiş ülkelerle kıyaslandığında varılacak sonuç ile bu dış borcun dünya ortalaması dikkate alınarak kıyaslanmasında varılacak sonuç farklı olacaktır. Haliyle ekonomiyi iyi göstermek için ikincisine yani dünya ortalamasına referansta bulunmak, tercih nedeni olabilir. Mesela Türkiye' nin toplam borcunun milli gelire oran $\% 141$ iken dünyada bu oranın \% 320'nin üzerinde olması, örnek olarak verilerek, Türkiye'nin ekonomisinin iyi bir profil çizdiği belirtilebilir. ${ }^{10}$

Bir diğer husus, yapılan analizlerde ele alınan zaman dilimidir; yani 1 yıllık, 3 yıllık, 5 yıllık, 10 yıllık vb. değerlendirmeler, örneğin ilgili dönemdeki siyasi otoritenin performansını değerlendirmek için etkili olabilir; ancak ülkenin yapısal sorunlarına dikkat çekmek için daha uzun bir zaman dilimine ihtiyaç olabilir. ${ }^{11}$ Örneğin Türkiye' nin yapısal sorunları için örneğin 50 yıllık bir dönem daha faydalı olabilir. Elbette ilgili dönemdeki siyasi otoritenin takip ettiği politikaların (ithal ikameci yerine ihracata dayalı politikalar, özelleştirmeye ağırlık verilmesi vb.) bu yapısal sorunlara veya üstünlüklere müspet veya menfi tesirlerinin olacağı inkâr edilemez. Haliyle bu makaledeki analizin çerçevesini belirleyecek hususlar dikkate alındığında ülke ekonomisinin yapısal durumunu ortaya koymak önemlidir. Ancak analize başlamadan önce, anlık bir fotoğraf çekildiğinde, neler görüldüğünün ortaya konması da gerekmektedir. Bu an (bu makalenin yazılma tarihi yani 2019 yılının ilk çeyreği), tamamlanan raporlar dikkate alındığında, 2018 Aralık ayı ve en uzak 2016 yılı, onun dışında ise mümkün olduğu ölçüde 2019 yılıdır. Veri tabanları dikkate alındığında ise mümkün olan en yakın tarihe ait veriler kullanılmaktadır. Diğer bir husus ise karşılaştırma yaparken, başarılı ülke (G8 ülkeleri) örneklerinden hareketle, ilgili alanda performansı yüksek ülkeler dikkate 
alınmaktadır. İlgili kurumların rapor ve veri tabanlarından oluşturulan Tablo 1,12 başlangıç olarak Türkiye'nin temel makroekonomik verilerini göstermektedir.

Tablo 1. Türkiye'nin Temel Makro Ekonomik Göstergeleri

(TL ve \$)

\begin{tabular}{|c|c|c|}
\hline Göstergeler & $2018 Y_{111}$ & 2017 Y111 \\
\hline Gayrisafi Yurtiçi Hasıla (GSYH-TL) & 3.740 .519 .000 .000 & 3.106 .537 .000 .000 \\
\hline Kişi Başına GSYH (\$) & 9.385 & 10.602 \\
\hline GSYH Büyüme Oranı (\%) & 3,8 & 7,4 \\
\hline $\begin{array}{l}\text { İşsizlik Oranı (2018 Yılı İçin Dönemsel- } \\
\text { Eylül) }\end{array}$ & 11,4 & 10,9 \\
\hline $\begin{array}{l}\text { Enflasyon (Yurt İçi Üretici Fiyat } \\
\text { İndeksi-\%) }\end{array}$ & 38,54 & 17,30 \\
\hline Enflasyon (Tüketici Fiyat İndeksi-\%) & 21,62 & 12,98 \\
\hline Bütçe Açı̆̆ı (TL) & 72.100 .000 .000 & 47.779 .000 .000 \\
\hline D1ş Ticaret Açığı $(\mathrm{TL})$ & 66.000 .000 .000 & 76.807 .000 .000 \\
\hline $\begin{array}{l}\text { Cari Açığın GSYH'ya Oranı (\%) (2018 } \\
\text { Tahmini) }\end{array}$ & 4,7 & 5,6 \\
\hline Yatırımların GSYH'ya Oranı (\%) & & 30 \\
\hline Tasarrufların GSYH'ya Oranı (\%) & & 25,4 \\
\hline 1 ABD Doları (28 Aralık İtibariyle-TL) & 5,27 & 3,82 \\
\hline $\begin{array}{l}\text { Toplam Brüt Diş Borç Stoku (2018 için } \\
\text { 2. Çeyrek) }\end{array}$ & 457.000 .000 .000 & 454.803 .000 .000 \\
\hline $\begin{array}{l}\text { Özel Sektör Diş Borç Stoku (2018 için } 2 . \\
\text { Çeyrek) }\end{array}$ & 317.200 .000 .000 & 317.600 .000 .000 \\
\hline
\end{tabular}

Kaynak: (Hazine ve Maliye Bakanlığı, 2018; Merkez Bankası, 2018; Merkez Bankası, 2017).

Tablo 1, mevcut veriler 1şığında yani 2018 yılı için Türkiye' nin büyüme oranının düştüğünü, bütçe açığının önemle düzeyde yükseldiğini, enflasyonun fırladığını, özel sektör dış borç yükünün çok yüksek olduğunu, işsizlik oranının önemli düzeyde olduğunu ve dolar karşısında Türk lirasının alım gücünde zayıflama olduğunu göstermektedir.

Mevcut veriler, gelişmiş ülkeler ile karşılaştırıldığında aşağıdaki tablo ortaya çıkmaktadır. Bu çerçevede Tablo 2,13 gelişmiş ülkeler olan G8 ülkeleri ile Çin ve Türkiye'ye ait verileri göstermektedir. 2018 yılına ait veriler tahmini olup, Genel Yönetim Bütçe Dengesine ilişkin veriler hem 2017 hem de 2018 için tahminidir. Ayrıca Rusya ve Çin'deki işsizlik oranı, mevsimsellikten arındırılmamıştır. 
Tablo 2. Ülke Karşılaştırmalı Temel Makro Ekonomik Göstergeler (GSYH için Milyar \$)

\begin{tabular}{|c|c|c|c|c|c|}
\hline \multirow[t]{2}{*}{ Ülkeler } & & \multicolumn{4}{|c|}{$\begin{array}{c}\text { Göstergeler } \\
\text { 2017-2018 (2018 Verileri Tahminidir) }\end{array}$} \\
\hline & $\begin{array}{l}\text { GSYH } \\
\text { Büyüme } \\
\text { Oranı }\end{array}$ & $\begin{array}{l}\text { GSYH } \\
\text { (SAGP) } \\
\text { (Milyar \$) }\end{array}$ & $\begin{array}{l}\text { GSYH } \\
\text { (Milyar \$) }\end{array}$ & $\begin{array}{l}\text { Kişi Başı } \\
\text { GSYH }\end{array}$ & $\begin{array}{l}\text { Cari İşlemler } \\
\text { Dengesi } \\
\text { (GSYH'ya Oranı) }\end{array}$ \\
\hline $\mathrm{ABD}$ & $2,2-2,9$ & $19.485-20.513$ & $19.485-20.513$ & $59.792-62.518$ & $(-) 2,3-(-) 2,5$ \\
\hline Almanya & $2,5-1,9$ & $\begin{array}{r}4.199-4.379 \\
.\end{array}$ & $\begin{array}{c}3.701-4.029 \\
.\end{array}$ & $44.769-48.670$ & $(+) 7,9-(+) 8,1$ \\
\hline $\begin{array}{l}\text { Birleşik } \\
\text { Krallık }\end{array}$ & $1,7-1,4$ & $2.925-3.034$ & 2.628-2.809 & $39.800-42.261$ & $(-) 3,8-(-) 3,5$ \\
\hline Fransa & $2,3-1,6$ & $2.856-2.969$ & $\begin{array}{l}2.588-2.795 \\
\end{array}$ & $39.933-42.931$ & $(-) 0,6-(-) 0,9$ \\
\hline İtalya & $1,5-1,2$ & $2.317-2.398$ & $1.939-2.087$ & $31.997-34.349$ & $(+) 2,8-(+) 2,0$ \\
\hline Japonya & $1,7-1,1$ & $5.443-5.632$ & $4.873-5.071$ & $38.449-40.106$ & $(+) 4,0-(+) 3,6$ \\
\hline Kanada & $3,0-2,1$ & $1.774-1.853$ & $1.653-1.734$ & $45.095-46.733$ & $(-) 2,9-(-) 3,0$ \\
\hline Rusya & $1,5-1,7$ & 4.016-4.180 & $1.578-1.576$ & $10.956-10.950$ & $(+) 2,2-(+) 6,2$ \\
\hline Çin & $6,9-6,6$ & $23.208-25.313$ & $12.015-13.457$ & 8.643-9.633 & $(+) 1,4(+) 0,7$ \\
\hline Türkiye & $7,4-3,8$ & 2.176-? & $851-763$ & $10.602-9.385$ & $(-) 5,6-(-) 4,7$ \\
\hline
\end{tabular}

Kaynak: (Hazine ve Maliye Bakanlığı, 2018; IMF, 2018).

Tablo 2'nin Devamı. Ülke Karşılaştırmalı Temel Makro Ekonomik Göstergeler

\begin{tabular}{|l|l|l|l|l|}
\hline \multirow{2}{*}{ Ülkeler } & \multicolumn{4}{|c|}{ Göstergeler } \\
& \multirow{4}{*}{ İşsizlik Oranı } & $\begin{array}{l}\text { Enflasyon } \\
\text { Oranı }\end{array}$ & Tasarruf Oranı & GY Bütçe Dengesi \\
\cline { 2 - 5 } & & $2,1-2,4$ & $18,9-19,0$ & $(-) 4,6-(-) 5,3$ \\
ABD & $4,4-3,8$ & $1,7-1,8$ & $28,0-28,5$ & $(+) 1,1-(+) 1,5$ \\
Almanya & $3,8-3,5$ & $2,7-2,5$ & $13,6-13,7$ & $(-) 2,3-(-) 1,8$ \\
Kirleşik & $4,4-4,1$ & & & \\
Frallik & & $1,2-1,9$ & $22,9-22,7$ & $(-) 2,6-(-) 2,4$ \\
İtansa & $9,4-8,8$ & $1,3-1,3$ & $20,3-20,1$ & $(-) 1,9-(-) 1,6$ \\
Japonya & $11,3-10,8$ & $0,5-1,2$ & $28,0-28,1$ & $(-) 4,2-(+) 3,4$ \\
Kanada & $2,9-2,9$ & $1,6-2,6$ & $20,8-20,8$ & Veri yok \\
Rusya & $6,3-6,1$ & $3,7-2,8$ & $27,3-27,8$ & $(-) 1,5-0$ \\
Çin & $5,2-5,5$ & $1,6-2,2$ & $44,9-44,4$ & $(-) 4,0-(-) 4,1$ \\
Türkiye & $3,9-4,0$ & $11,9-20,8$ & $25,9-25,3$ & $(-) 1,9-(-) 1,9$ \\
\hline
\end{tabular}

Kaynak: (Hazine ve Maliye Bakanlığı, 2018; IMF, 2018).

Tablo 2, Türkiye' nin büyüme oranının göreli olarak iyi düzeyde olduğunu ancak bunu her hâlükârda cari açık vererek (ithalat büyüktür ihracat) yaptığını göstermektedir. Enflasyondan dolayı, kişi başına gelirin satın alma gücünün de azalacağını söylemek mümkündür. Buna doların TL karşısında kazandığı değer de eklenince, ekonominin küçülme sürecine girdiğini söylemek mümkündür. Yine mevcut veriler ışığında, bunu, işsizlikteki artışın takip edeceği 
de öngörülebilir. Bu tablo, Türkiye'nin üretime önem vermesi gerektiğini ortaya koymaktadır. Ancak ne tür bir üretim?

Tablo 3, 1960-2017 yılları arasında incelemeye konu edilen Çin ve G8 ülkelerinin gayri safi yurtiçi hasılalarındaki sektör dağılımını göstermektedir. Ancak 2017 yılı verilerinin mümkün olmadığı yerde 2016 verileri kullanılmıştır. Tarım sektörüne balık ve ormancılık dâhildir. İnşaat, kaynak veri tabanı açısından sanayi sektörü içinde yer almaktadır. Boş bırakılan yerlerde veri kaydı yoktur. Ancak bu değerlendirme yapmaya engel nitelikte değildir.

Tablo 3. Gelişmiş Ülkeler Düzeyinde Sektörlerin Gayri Safi Yurtiçi Hasılaya Oranı

\begin{tabular}{|c|c|c|c|c|c|c|c|c|c|}
\hline \multirow[t]{2}{*}{ Ülkeler } & \multicolumn{3}{|c|}{ Tarım } & \multicolumn{3}{|c|}{ Sanayi } & \multicolumn{3}{|c|}{ Hizmet } \\
\hline & 1960 & 2016 & 2017 & 1960 & 2016 & 2017 & 1960 & 2016 & 2017 \\
\hline ABD & & 1,01 & & & 18,88 & & & 77,02 & \\
\hline Almanya & & 0,55 & 0,63 & & 27,46 & 27,59 & & 62,05 & 61,89 \\
\hline Birleşik Krallık & & 0,53 & 0,51 & & 17,98 & 18,57 & & 70,60 & 70,06 \\
\hline Fransa & 10,51 & 1,45 & 1,50 & 29,81 & 17,56 & 17,36 & & 70,33 & 70,23 \\
\hline İtalya & & 1,89 & 1,92 & & 21,43 & 21,36 & & 66,39 & 66,28 \\
\hline Japonya & & 1,15 & & & 29,30 & & & 68,77 & \\
\hline Kanada & & 1,42 & & & 27,53 & & & 64,65 & \\
\hline Rusya & & 4,18 & 4,01 & & 29,28 & 30,04 & & 56,62 & 56,18 \\
\hline Çin & 23,17 & 8,56 & 7,91 & 44,39 & 39,88 & 40,45 & & 51,55 & 51,62 \\
\hline Türkiye & 54,91 & 6,18 & 6,08 & 17,32 & 28,18 & 29,15 & 25,84 & 53,76 & 53,36 \\
\hline
\end{tabular}

Kaynak: (World Bank, 2019a; World Bank 2019b; World Bank 2019c).

Tablo 3, gelişmiş ülkelerde en önemli sektörün hizmet sektörü olduğunu; Çin ve G8 ülkelerinden Rusya hariç, hizmet sektörünün gayri safi yurtiçi hasıladaki oranının yüzde 60'ların üzerinde olduğunu göstermektedir. İkinci önemli sektör sanayi olup, yine Çin ve G8 ülkelerinden Rusya hariç, sanayi sektörünün gayri safi yurtiçi hasıladaki oranının yüzde 30'ların altında olduğu görülmektedir. Son olarak tarım sektörü de Çin ve G8 ülkelerinden Rusya hariç, gayri safi yurtiçi hasıladaki oranı, yüzde ikilerin altındadır. Türkiye açısından ise tarım ve sanayi, göreli olarak Türkiye için hala önemli durumdadır. Gelişmiş ülkelerle karşılaştırıldığında ise Türkiye için gelişme potansiyeli hizmet sektöründedir. Ancak bu da kaynak tahsisi açısından değerlendirildiğinde, bir sektöre aktarılan kaynakların diğer sektörlerden mahrum edilmesi durumunda, bu, diğer sektörlerin küçülmesi gerektiği manasına gelmektedir. ${ }^{14} \mathrm{O}$ halde konu Türkiye için büyüme değil, gayrisafi yurtiçi hasılanın büyümesine neden olacak yeni bir kalkınma konusudur. Bu açıdan da gelişmiş ülkelerle karşılaştırma yapıldığında, yine dikkat çeken sektör hizmet sektörü olmaktadır. Tablo 4, cari fiyatlarla sektörlerin ve alt sektörlerin gayrisafi yurt içi hasıladaki paylarını göstermekledir. 
Tablo 4. Gelişmiş Ülkeler Düzeyinde Sektörlerin Gayri Safi Yurtiçi Hasılaya Oranı

\begin{tabular}{|c|c|c|}
\hline & 2016 & 2017 \\
\hline Tarım & 6,2 & 6,1 \\
\hline Tarım, Ormancılık ve Balıkçılık & 6,2 & 6,1 \\
\hline Sanayi & 28,2 & 29,3 \\
\hline Madencilik ve taş ocakçıllı̆̆ & 0,8 & 0,9 \\
\hline İmalat sanayi & 16,6 & 17,6 \\
\hline Elektrik, gaz, buhar vb. üretimi ve dağıtımı & 1,3 & 1,2 \\
\hline Su temini, kanalizasyon ve atık yönetimi & 0,9 & 1,0 \\
\hline İnşaat & 8,6 & 8,6 \\
\hline Hizmetler & 53,7 & 53,2 \\
\hline Toptan ve perakende ticaret & 11,4 & 11,9 \\
\hline Ulaştırma ve depolama & 7,6 & 7,7 \\
\hline Konaklama ve yiyecek hizmeti faaliyetleri & 2,6 & 2,7 \\
\hline Bilgi ve iletișim & 2,4 & 2,5 \\
\hline Finans ve sigorta faaliyetleri & 3,3 & 3,2 \\
\hline Gayrimenkul faaliyetleri & 7,7 & 7,2 \\
\hline Mesleki, bilimsel ve teknik faaliyetler & 2,3 & 2,4 \\
\hline İdari ve destek hizmet faaliyetleri & 3,0 & 3,1 \\
\hline Kamu yönetimi ve savunma, zorunlu güvenlik & 4,6 & 4,3 \\
\hline Eğitim & 4,4 & 4,1 \\
\hline İnsan sağlı̆̆ı ve sosyal hizmet faaliyetleri & 2,6 & 2,4 \\
\hline Kültür, sanat, eğlence, dinlence ve spor & 0,9 & 0,9 \\
\hline Diğer hizmet faaliyetleri & 1,0 & 0,9 \\
\hline Hane halkının işveren olarak faaliyetleri & 0,05 & 0,05 \\
\hline Sektörler Toplamı & 88,1 & 88,6 \\
\hline Vergi-Sübvansiyon & 11,9 & 11,4 \\
\hline Toplam & 100 & 100 \\
\hline
\end{tabular}

Kaynak: (Türkiye İstatistik Kurumu [TÜIK], 2019a)

Tablo 1 ve Tablo 4 dikkate alındığında, 1) yetersiz tasarruflardan dolayı dış yatırım, 2) imalat sanayi ve 3) bilgi ve iletişim teknolojilerini değerlendirilmesi özel bir öneme sahiptir.

\section{Diş Yatırım}

Yatırımların finansmanında önemli bir kaynak olan dış yatırımlar, 1984-2002 döneminde 14,6 milyar ABD doları iken, 2003-2017 döneminde 193,1 milyar dolara ulaşmıştır. 2018 Ocak-Ekim döneminde ise \%2,8 azalarak 9,2 milyar dolar olarak gerçekleşmiştir (Ticaret Bakanlığı, 2018: 41). Bununla birlikte 2007 yılında tavan yapan dış yatırımların iniş çıkışta olduğu ama her hâlükârda 2007 yılının baz alınması durumunda bir düşüş içerisinde olduğunu söylemek mümkündür. 
Tablo 5. Yıllara Göre Doğrudan Yabancı Yatırımlar

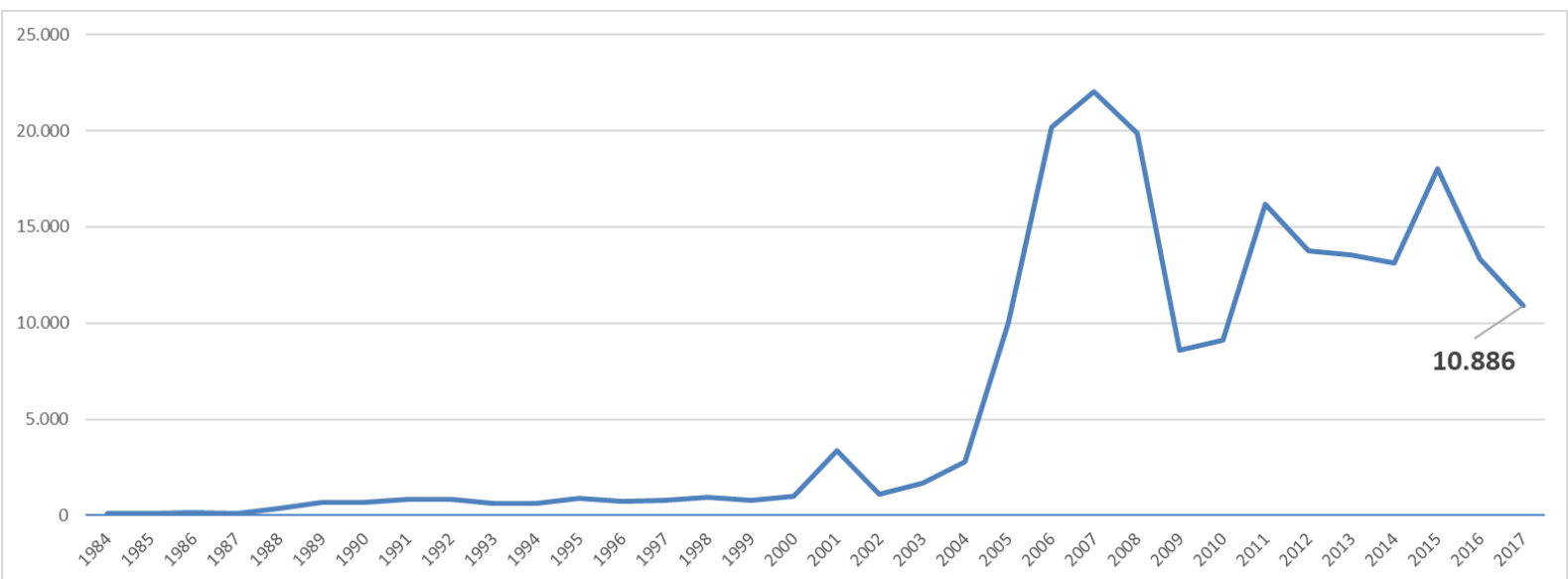

Kaynak: (Türkiye Cumhuriyeti Merkez Bankası'ndan aktaran Ticaret Bakanlığı, 2018:41)

2000'li yılların başında yapısal reformlara girişen özellikle de Avrupa Birliği ile işbirliği halinde hareket eden Türkiye'nin dış yatırım çekme potansiyeli bu dönemde artmış, 2008 sonrası ise Avrupa Birliğiyle ilişkilerin gerilemesine bağlı olarak düşme ve dalgalanma eğilimindedir. Yabancı yatırımcıların ülkelere göre dağılımı (Tablo 6), bu çıkarımı kuvvetlendirmektedir.

Tablo 6.Yabancı Yatırımların Ülkelere Göre Dağılımı

(Milyon \$)

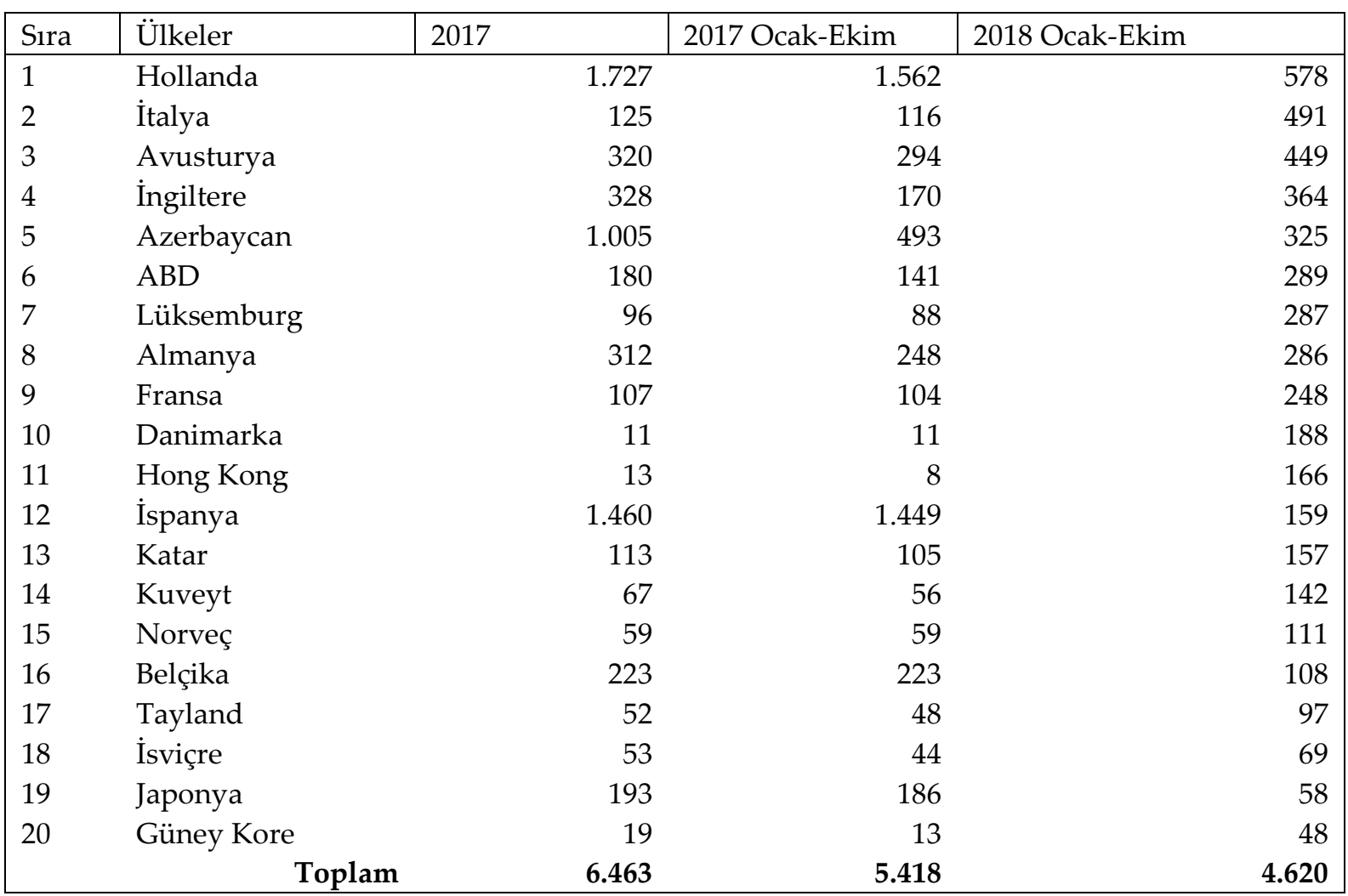

Kaynak: (Türkiye Cumhuriyeti Merkez Bankası'ndan aktaran Ticaret Bakanlığı, 2018:44) 
Tablo 6'ya göre 20 ülkenin 13'ü, Batı demokrasisi içerisinde yer alan ülkelerdir ve Batı demokrasilerini, ${ }^{15}$ hukukun üstünlüğ̈̈, adalet ve insan hakları ilkelerinden uzak tutmamak gerekir. ${ }^{16}$ Yine bu 13 Batı demokrasisinden 12'si (ABD hariç), Avrupa Birliği üyesidir. Haliyle Avrupa Birliği müktesebatı ile uyumlu hareket etmek, Avrupa kökenli yatırımlar için önemlidir. Tabloya bir bütün olarak bakıldığında ise Azerbaycan, Katar ve Kuveyt hariç, tüm ülkeler otoriter rejimler dışında yer alan ülkelerdir. Haliyle demokrasi ve yabancı yatırımlar arasında bir ilişki olduğunu kabul etmek yerinde olacaktır. Yabancı yatırımcının en çok ihtiyaç duyacağı hak arama ve hızlı adalet mekanizmaları, dış yatırımların geleceği ve Türkiye ekonomisi için önemlidir.

Türkiye okuması içeriden ve dışarıdan farklı olabilir. Daha sağlıklı bir okumanın içeriden olması gerektiği de söylenebilir. Lakin dış yatırımcı, okumasını, içeriden yapmamaktadır. Haliyle algıların yönetimi de önemlidir. Türkiye 2018 yılında dünya demokrasi indeksinde, 167 ülke içerisinde 110. sırada yer almaktadır (Burrows, 2019). Kredi derecelendirme kuruluşlarının parametrelerinden birisi, hukukun üstünlügüüdür. $\mathrm{Bu}$ oran Moody's değerlendirmesinde yüzde 10, S\&P değerlendirmesinde \% 6'dır. Yönetim etkinliği parametresi ise Moody's için yüzde 16, S\&P için \% 11, Fitch için yüzde 14'tür (Haspolat'tan aktaran, Yenipazarlı, Bulut ve Kavak, 2017: 85). Haliyle ülkelerin bu parametreler üzerinden alacakları puan önemlidir. Yine Türkiye'nin beş yıl vadeli borcunu iflasa karşı sigortalamanın maliyetini gösteren Kredi Risk Primi (Tokyol, 2018, 24 Ekim), kredi derecelendirme grupları Moody's, Fitch ve DBRS için sırasıyla Ba3 (son güncelleme 17 Ağustos 2018 itibariyle), BB (son güncelleme 13 Temmuz 2018 itibariyle) ve BB (yüksek-son güncelleme 21 Temmuz 2016 itibariyle) olup, kırmızı ile işaretlenmiştir yani negatif bir görünüme sahiptir (World Government Bond, 2019).

Kaldı ki ulusal düzeyde de Tüketici Güven Endeksi, ${ }^{17}$ gittikçe düşmektedir. 2004 yılının Ocak ayında arındırılmamış tüketici güven endeksi 98,2 iken, 2019 Ocak ayında 58,5'dir. Tablo 7, yıllar itibariyle Ocak, Şubat ve Mart ayları (makalenin yazıldığı dönem dikkate alınarak) çerçevesinde tüketici güven endeksini göstermektedir. 
Tablo 7. Tüketici Güven Endeksi

\begin{tabular}{|llll|}
\hline & Ocak & Şubat & Mart \\
\hline $\mathbf{2 0 0 4}$ & 98,2 & 98,7 & 97,8 \\
$\mathbf{2 0 0 5}$ & 92,2 & 92,0 & 88,8 \\
$\mathbf{2 0 0 6}$ & 88,5 & 87,9 & 88,5 \\
$\mathbf{2 0 0 7}$ & 78,6 & 79,5 & 79,2 \\
$\mathbf{2 0 0 8}$ & 78,9 & 74,4 & 68,7 \\
$\mathbf{2 0 0 9}$ & 58,3 & 60,8 & 61,6 \\
$\mathbf{2 0 1 0}$ & 66,0 & 68,6 & 71,5 \\
$\mathbf{2 0 1 1}$ & 78,1 & 80,3 & 80,2 \\
$\mathbf{2 0 1 2}$ & 79,0 & 79,6 & 79,3 \\
$\mathbf{2 0 1 3}$ & 75,8 & 76,7 & 74,9 \\
$\mathbf{2 0 1 4}$ & 72,4 & 69,2 & 72,7 \\
$\mathbf{2 0 1 5}$ & 67,7 & 68,1 & 64,4 \\
$\mathbf{2 0 1 6}$ & 71,6 & 66,6 & 67,0 \\
$\mathbf{2 0 1 7}$ & 66,9 & 65,7 & 67,8 \\
$\mathbf{2 0 1 8}$ & 72,3 & 72,3 & 71,3 \\
$\mathbf{2 0 1 9}$ & 58,5 & & \\
\hline
\end{tabular}

Kaynak: (TÜIK, 2019b)

Tablo 7'den de rahatlıkla anlaşılacağı üzere, tüketici de ülke ekonomisinin geleceği hakkında iyimser değildir. Haliyle bu da harcamaların azalmasına, üretimin azalmasına, ekonominin küçülmesine ve yeni yatırımların azalmasına neden olacaktır. Kısacası, mevcut veriler ışı̆̆ında, yabancı yatırımcı kadar ülkedeki tüketici de ülke ekonomisinin geleceğine karşı iyimser yaklaşmamaktadır.

\section{İmalat Sanayi}

2014 yılı verilerine göre, imalat sanayi ihracatı, ülke toplam ihracatının \%93.3'ünü oluştururken, imalat sanayi ithalatı da toplam ithalatın \%77.5' ini teşkil etmektedir (Genç, 2016: 5). İmalat sanayi ithalatında öne çıkan sektörlerin başında kimyasal madde ve ürünler gelmektedir. Bunu sırasıyla ana metal sanayi, makine ve teçhizat, kok kömürü, rafine edilmiş petrol ürünleri ve nükleer yakıt ile motorlu kara taşıtı izlemektedir. 2014 yılı itibarıyla imalat sanayi ithalatının \%18.6'sını kimyasal madde ve ürünler oluştururken, \%14.1'ini ana metal sanayi, \%11.6'sını makine ve teçhizat, \%10'unu kok kömürü, rafine edilmiş petrol ürünleri ve nükleer yakıt, \%9.8'ini de motorlu kara taşıtı oluşturmaktadır. Bu 5 sektör imalat sanayi ithalatının \%64.1'ine tekabül etmektedir. Yine 2014 yılı itibarıyla toplam ithalatın üçte ikisi, hammadde ve ara malından oluşmaktadır. Yatırım (sermaye) mallarının ise toplam ithalattaki payı ise \%15 civarındadır. (Genç, 2016: 7-8).

İmalat sanayi sektörleri ithal girdi oranları dikkate alındığında ilk 10 sektör aşağıdaki gibidir; 18

a) Kok kömürü, rafine edilmiş petrol ürünleri ve nükleer yakıtların oranı \% 50,3,

b) Radyo, televizyon, haberleşme teçhizatı ve cihazları \% 36,4, 
c) Mobilya ve başka yerde sınıflandırılmamış diğer ürünler \% 31,3,

ç) Tibbi aletler, hassas optik aletler ve saat $\% 26,9$,

d) Dabaklanmış deri, bavul el çantası, saraciye ve ayakkabı \% 22,9,

e) Ana metal sanayi \% 22,7,

f) Plastik ve kauçuk ürünleri \% 22,1,

g) Büro, muhasebe ve bilgi işleme makineleri \% 20,9,

ğ) Kimyasal madde ve ürünleri \% 18,7,

h) Motorlu kara taşıtı ve römorklar \% 18,6 (Küçükkiremitçi'den aktaran Genç, 2016: 9) .

Yukarıdaki verilerden de anlaşılacağı üzere, Türkiye imalat sanayinin yurtdışına bağımlı yapısı, imalat sanayinin dış ticaret açı̆̆ı vermesine neden olmaktadır. Haliyle bu ürünlerin tedarikindeki bir tarife değişikliği, kur yükselmesi veya ithalatçı ülke kotası, ülke ekonomisinde önemli etkiler yaratmaktadır.

2000-2014 yılı verileri dikkate alındığında, ara malı dış ticaret dengesinin Türkiye'nin toplam dış ticaret dengesi ile karşılaştıııldığında, ara malı dış ticaretinden kaynaklanan açığın, genelde ülke dış ticaret açığının üzerinde olduğu söylenebilir. 2003-2007 yılları arasındaki açık daha da belirgindir (Genç, 2016: 11). Tablo 8, ara malı dış ticaret dengesinin Türkiye toplam dış ticaret dengesi ile karşılaştırmasını göstermektedir.

Tablo 8. Ara Malı Dış Ticaret Dengesinin Türkiye Toplam Dış Ticaret Dengesi İle Karşılaştırması

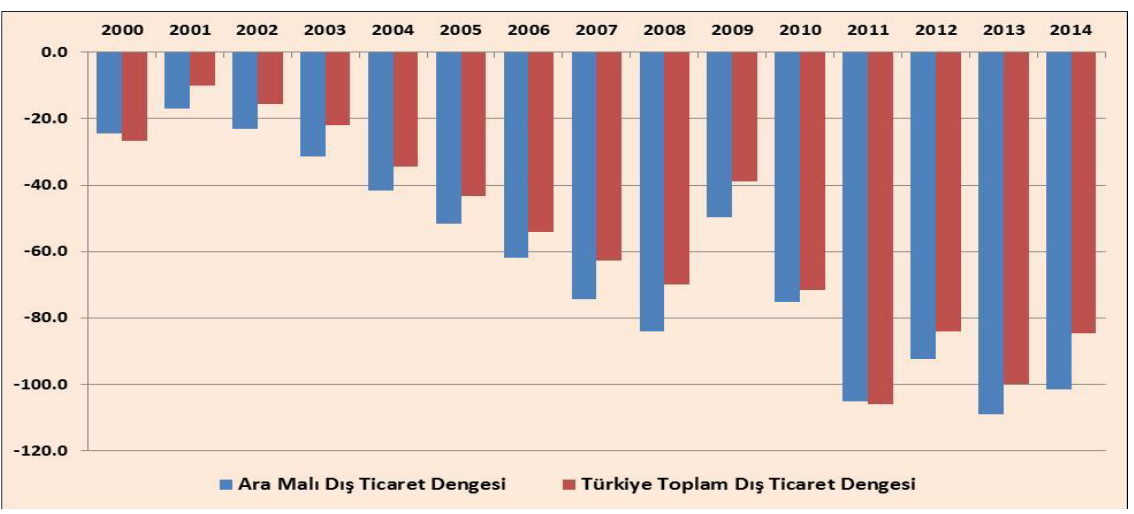

Kaynak: (Türkiye İstatistik Kurumundan aktaran Çelik, 2016:11)

Sonuç olarak, Türkiye'nin ara malı ithalatını yaptığı ürünlerin/emtiaların Türkiye'de üretimini, nükleer enerji de dâhil olmak üzere, stratejik bir amaç haline getirmesi gerektiği söylenebilir. Mevcut gelişmeler, Türkiye'nin bu konuyu dikkate almaya başladığını göstermektedir. ${ }^{19}$

\section{Bilgi ve İletişim Hizmetleri}

Tümdengelimci bir bakış açısıyla yani bu anlamda bilgi tabanlı ekonomi paradigmasıyla değerlendirme yapıldığında, göze çarpan bilgi ve iletişim alt sektörüdür. Bu, günümüz ekonomik modeli yani bilgi tabanlı ekonomi için son derece düşük bir paydır. Tablo 9, gelişmiş ülkelerin hizmet ihracatında bilgi ve iletişim teknolojilerinin payını göstermektedir. 
Tablo 9. Gelişmiş Ülkeler Düzeyinde Bilgi ve İletişim Teknolojileri Hizmetlerinin İhracata Oranı

\begin{tabular}{|l|c|c|c|}
\hline \multirow{2}{*}{ Ülkeler } & \multicolumn{3}{|c|}{ Ylllara Göre Oranlar } \\
\cline { 2 - 4 } & $\mathbf{1 9 8 8}$ & $\mathbf{2 0 1 4}$ & $\mathbf{2 0 1 5}$ \\
\hline ABD & $\mathbf{1 4 , 0 9}$ & $\mathbf{2 2 , 0 4}$ & $\mathbf{2 2 , 7 1}$ \\
Almanya & $\mathbf{1 5 , 6 6}$ & 39,31 & 39,70 \\
Birleşik Krallık & & 35,25 & 35,67 \\
Fransa & 33,53 & 39,49 & 40,64 \\
İtalya & 16,95 & 31,85 & 30,80 \\
Japonya & & 24,85 & 22,95 \\
Kanada & 47,12 & 42,57 & 40,76 \\
Rusya & & 32,30 & 32,07 \\
Çin & 10,64 & 40,64 & 38,15 \\
Türkiye & & 1,22 & 0,98 \\
\hline
\end{tabular}

Kaynak: (World Integration Trade Solution [WITS], 2019)

Tablo 9, Türkiye'nin hizmet ihracatında bilgi ve iletişim teknolojileri payının yüzde birler civarında olduğunu göstermektedir. Gelişmiş ülkeler düzeyinde bu, yüzde 20'lerin üzerindedir. Dahası, 181 ülke içerisinde yüzde birden daha az payı olan üç ülke vardır: Türkiye, Meksika ve Bhutan (World Integration Trade Solution [WITS], 2019). ${ }^{20}$ Bu veriyi, aynı zamanda bir fırsat yani Türkiye'nin performansını geliştirebileceği bir sektör olarak ta yorumlamak mümkündür.

Bununla birlikte bilgi ve iletişim teknolojilerine dikkat çekilmesinin nedeni, ekonomik büyümeyi açıklamaya çalışan dışsal ve içsel büyüme kuramlarından kaynaklanmaktadır. Dışsal büyüme kuramı ekonomik büyümeyi belirleyen faktörlere yani sermaye, işgücü, doğal kaynaklar ve teknoloji unsuruna (Kaya, 2004a: 269) vurgu yaparken, içsel büyüme kuramı bilgi birikimi, araştırma ve geliştirme ile insan sermayesine (Kaya, 2004b: 297-299) vurgu yapmaktadır. Ancak büyümeyi gerek dişsal gerekse içsel faktörlerin birlikteliğiyle değerlendirmek yerinde olacaktır. Buraya kadar anlatılanlardan da görüleceği üzere gelişmiş ülkelerdeki veriler, teknoloji, inovasyon ve insan sermayesinin bir sentezi olan bilgi ve iletişim teknolojilerinin (Endüstri 4.0 ve Endüstri 5.0 odaklı olmak üzere) önemini gözler önüne sermektedir. Haliyle Türkiye için büyümeden ${ }^{21}$ ziyade bilgi ve iletişim teknolojilerine dayalı kalkınmayı amaçlamak tercih nedeni olmalıdır. ${ }^{22}$

Dünya Ekonomik Forumu'nun 2016-2017 dönemini kapsayan Küresel Rekabetçilik Raporu'na göre, Türkiye, 138 ülke arasından 55. sırasında yer almıştır. İlk 10 ülke sırasıyla İsviçre, Singapur, ABD, Hollanda, Almanya, İsveç, İngiltere, Japonya ve Hong Kong olmuştur (World Economic Forum, 2016: 7. Etkinlik çekişli ekonomi (düzey 2) ile yenilikçi çekişli ekonomi (düzey 3) arasında konumlandırılan Türkiye (Gümrük ve Ticaret Bakanlığı, 2017: 14-15), yenilikçilik endeksinde 71 siradadır (World Economic Forum, 2016: 50).

Bu konudaki tartışmalar eğitimin önemine işaret etmektedir. Makine Mühendisleri Odası'na ait raporda yer alan tespitle: 
“Ülkemizin, üretim, tasarruf-yatırım, istihdam, ihracat ve ithalatın yapısı, teknoloji düzeyi, dış talep bağımlılığı, cari açık, sermaye hareketlerinin serbest giriş-çıkışı ve aşırı borçlanma ile hayli örselenmiş olan ekonomisinde, nitelikli bir üretimin sağlanması, öncelikle "Teknolojiyi yalnızca kullanan değil, üreten bir toplum olma" odaklı anlayışı hakim kılmakla başlayacaktır. Bu anlayış, eğitim sisteminden bütünlüklü bilim, sanayi ve teknoloji politikalarına uzanan sosyoekonomik politikaları içermektedir.

Bir bütün olarak gericiliğin karanlığına teslim edilmiş eğitim sisteminde bilim ve akıldan uzaklaşıldığı müddetçe, daha genel bir ifadeyle toplumsal ve siyasal alanda aydınlanmayı, ilerici düşünceyi, demokrasiyi mahkum eden mevcut anlayış ortadan kalkmadığ1 müddetçe, teknoloji üreten bir toplum olma idealinden bahsetmek de mümkün olmamaktadır. Bilimsel düşünce ve bilimsel üretimi, özgür düşünceyi merkezine alan bir eğitim sisteminin inşa edilmesi en öncelikli adımlar arasında olmalıdır." (Makine Mühendisleri Odası, 2018: 45).

Eğitimin nihai hedefi, 1) bir ülkenin ideolojisine uygun vatandaş yetiştirmek, 2) o ülkenin ekonomisine uygun vatandaş yetiştirmektedir. Tümdengelimci bir bakış açısıyla, örneğin Türkiye ile Orta Doğu ve Avrupa ülkeleri karşılaştırıldığında; Türkiye'nin takip etmesi gereken seyir bellidir. Bu çerçevede Türkiye' nin laik eğitimi kökleştirmesi ve bilimsel eleştirel bakış açısına sahip, pozitif bilimlere hak ettiği yeri veren bir noktayı hedeflemesi gerekmektedir. Din eğitiminin devlet kontrolünde ve zorunlu olması gerektiğinin altını çizmekle birlikte (öbür türlü din eğitimi istenmeyen grup veya oluşumların tekeline geçmektedir; lakin devletin de bunu Orta Doğu ülkelerine özgü bir anlayışla yapmaması gerekmektedir) ${ }^{23}$, bilgi tabanlı ekonomi ve bilgi toplumunun ihtiyacı olan eğitimin verilmesi, müfredatların buna göre hazırlanması ve eğitim kurumlarının bu çerçevede liyakat esasına dayalı olarak yapılandırılması gerektiği de aşikârdır. Eğitim Reformu Girişimi'nin Eğitim İzleme Raporu (2016-2017)'nun referansta bulunduğu aşağıdaki sonucun, eğitim meselesini özetlemeye yeterli olduğu söylenebilir.

...16-65 yaş arası yetişkinlerin yetkinlikleri 'sözel beceriler', 'sayısal beceriler' ve 'teknoloji yoğun ortamlarda problem çözme becerileri' odağında değerlendiriliyor. OECD'nin raporuna göre Türkiye'deki yetişkinler her üç alanda da OECD ortalamasının oldukça aşağısında yer alıyor; sözel ve sayısal becerilerde Türkiye'den daha düşük performans gösteren sadece Şili bulunuyor, problem çözmede ise Türkiye OECD ülkeleri arasında son basamakta. Bu durum Türkiye'de birtakım temel becerileri 15 yaşında edinememiş olan çok sayıdaki çocuğun kendilerine iş, eğitim hayatı ve toplumsal hayata aktif biçimde katılma noktasında gerekli olan donanımı ilerleyen yıllarda da edinemediğini gösteriyor. Özellikle PIAAC ile birlikte düşünüldügünnde PISA ve TIMSS verileri geleceğin yetişkinlerinin yeterliklerini göstermesi açısından toplumların ekonomik kalkınması, refahı ve rekabetçiliği noktasında önemli işaretler veriyor. Dolayısıyla, PISA ve TIMSS çıtılarına salt ekonomik yarar açısından yaklaşmak sakıncalı olsa da değerlendirmelerin bu yönünü de kullanmak; bulguları, çocuğun hem bugün hem de gelecekteki başarısına ve iyi olma halini dikkate alan bütünlüklü bir bakışla ele almak yararlı olabilir (Eğitim Reformu Girişimi, 2017: 135-136).

Kısacası laik, bilimsel eleştirel bakış açısına sahip, pozitif bilimleri yadsımayan, teknoloji odaklı, çocuğun yeteneklerini ortaya çıkarmaya çalışan, demokratik ve özgür bireyler yetiştirmeyi amaçlayan bir eğitim şarttır. Ve unutulmamalıdır ki politik ekonomi çerçevesinde tavır alan ülkeler bunu mikro ve makroekonominin kuralları (faiz, enflasyon, kur değişimleri 
ve bunların tüketici ve piyasa kararlarına etkisi) ile uluslararası ticaretin (kotalar, tarifeler vb.) belirleyici özelliklerine göre yapmaktadır.

\section{Sonuç ve Değerlendirme}

Türkiye ekonomisinin geleceğine ilişkin senaryolar, iktisat disiplininin dinamik yapısından dolayı, hırçın tartışmalara neden olabilmektedir. Mevcut veriler ışığında (2018 yılı ve sonrası için] Türkiye'nin büyüme oranının düştügünü, bütçe açığının önemle düzeyde yükseldiğini, enflasyonun firladığını, özel sektör dış borç yükünün çok yüksek olduğunu, işsizlik oranının önemli düzeyde olduğunu ve dolar karşısında Türk lirasının alım gücünde zayıflama olduğunu söylemek mümkündür.

Mevcut veriler, Türkiye'nin büyüme oranının göreceli olarak iyi düzeyde olduğunu ancak bunu cari açık vererek yaptığını ortaya koymaktadır. Enflasyon ve satın alma gücünü azalmasından dolayı, ekonominin küçülme sürecine girdiğini, bunu, işsizlikteki artışın takip edeceğini söylemekte mümkündür.

Gelişmiş ülkelerde en önemli sektör, hizmet sektörüdür. Bu oran, Çin ve G8 ülkelerinden Rusya hariç, gayri safi yurtiçi hasılanın yüzde 60'ından fazlasına tekabül etmektedir. İkinci önemli sektör sanayi olup, bu oran, yine Çin ve G8 ülkelerinden Rusya hariç, gayri safi yurtiçi hasılanın yüzde 30'unu geçmemektedir. Son olarak tarım sektörü de Çin ve G8 ülkelerinden Rusya hariç, gayri safi yurtiçi hasıladaki oranı, yüzde ikilerin altındadır. Türkiye açısından ise tarım ve sanayi, göreli olarak Türkiye için hala önemli durumdadır. Gelişmiş ülkelerle karşılaştırıldığında ise Türkiye için gelişme potansiyeli hizmet sektöründedir. Ancak Türkiye için konu büyüme değil, kalkınmadır. Bu çerçevede dış yatırım, imalat sanayi ile bilgi ve iletişim teknolojilerini değerlendirilmesi özel bir öneme sahiptir.

2000'li yılların başında Avrupa Birliği ile işbirliği halinde hareket eden Türkiye'nin dış yatırım çekme potansiyeli bu dönemde artmış, 2008 sonrası ise Avrupa Birliğiyle ilişkilerin gerilemesine bağlı olarak düşme ve dalgalanma göstermektedir. Türkiye imalat sanayinin yurtdışına bağımlı yapısı, imalat sanayinin dış ticaret açı̆̆ı vermesine neden olmakta ve bu ürünlerin tedarikindeki bir tarife değişikliği, kur yükselmesi veya ithalatçı ülke kotası, ülke ekonomisinde önemli olumsuz etkiler yaratmaktadır. Bilgi ve iletişim teknolojileri açısından ise Türkiye'nin hizmet ihracatındaki payı yüzde birler civarındadır. Gelişmiş ülkeler düzeyinde bu, yüzde 20 'lerin üzerindedir.

Türkiye'de tasarruf eksikliği dikkate alınırsa yabancı yatırımlar ayrı bir önem kazanmaktadır. Ancak demokrasi ve yabancı yatırımlar arasında bir ilişki vardır. Yabancı yatırımcının en çok ihtiyaç duyacağı hak arama ve hızlı adalet mekanizmaları, dış yatırımların geleceği ve Türkiye ekonomisi için önemlidir. Türkiye'nin ara malı ithalatını yaptığı emtiaların Türkiye'de üretimi, nükleer enerji de dâhil olmak üzere, stratejik bir amaç olmalıdır. Mevcut gelişmeler Türkiye'nin bu konuyu dikkate almaya başladığını göstermektedir. Eğitimin tartışmasız önemi her alanda kendini hissettirmesine rağmen, bilgi ve iletişim teknolojileri açısından ayrı bir öneme sahiptir. Laik, bilimsel eleştirel bakış açısına sahip, pozitif bilimleri yadsımayan, teknoloji odaklı, çocuğun yeteneklerini ortaya çıkarmaya çalışan, demokratik ve özgür 
bireyler yetiştirmeyi amaçlayan bir eğitim şarttır-Eğitim aynı zamanda demokrasi ve kalkınmanın alt yapısıdır (Esfender, 2018: 182-210).

Türkiye ile Orta Doğu ve Avrupa ülkeleri karşılaştırıldığında; Türkiye'nin takip etmesi gereken seyir bellidir. Bu elbette, diğer ülkelerle iletişim içerisinde olmayı göz ardı eden bir bakış açısı değildir. Ancak kötü örnek, örnek değildir düşüncesinden hareketle, standartları yükseltmeyi gaye edinen bir bakış açısıdır. Bunlar gerçekleştirildiğinde politik ekonominin uluslararası aktörlerinin Türkiye için arzu edilmeyen niyetleri, zaten amacına ulaşamayacaktır. O anlamda uluslararası ilişkiler açısından güvenlik sorunu olmayan yahut düşmanları, dostlarından fazla olan devlet yok gibidir. Diğer bir ifadeyle, devlet devletin kurdudur (Terzi, 2018: 11). Ancak tecrübeli devletler bilirler ki savaş yapmak çok daha maliyetlidir -Avrupa'nın savaşlarla dolu tarihi dikkate alındığında, savaşmak yerine ticaret yapılarak zenginleşmenin daha kolay sağlanabileceği düşüncesiyle tesis edilen ve bunun içinde demokrasi ve hukukun üstünlüğünü önceleyen Avrupa Birliği örneği akılda tutulmalıdır. O halde çözüm; barış, demokrasi, insan hakları, hukukun üstünlüğü, eğitim, insan kaynağına yatırım ve inovasyon ile Türkiye ekonomisinin yapısal sorunlarına odaklanmaktır.

\section{Kaynakça}

Akkaya, Murat. (2019). “Gelişen piyasalarda doğrudan yabancı sermaye yatırımı, ekonomik özgürlük ve ekonomik büyüme ilişkisi" . TESAM Akademi Dergisi, 6 (1), 283-303.

Asian Infrastructure Investment Bank, (2019, 1 Mart). Members and prospective members of the bank, Erişim adresi, (08 Ekim 2019): https://www.aiib.org/en/about-aiib/governance/members-of-bank/index.html

Bayraktaroğlu, Memduh. (2018, 18 Aralık). Cari açık ve ekonominin geleceği [Video]. Erişim adresi: https://www.youtube.com/watch?v=x1-9LoCvgjA.

BBC, (2016, 18 Ocak). "Falling oil prices : How are countries being affected?", Erişim adresi, (21 Mart 2019): https://www.bbc.com/news/world-35345874.

Behnke, Tommy. (2006, 31 Mayı). "Currency manipulation by the United States is alive and well”, Mises Institute, Erişim adresi, (20 Mart 2019): https://mises.org/wire/currency-manipulation-united-statesalive-and-well.

Burrows, Ian. (2019, 10 Ocak). Chart of the day: Europe dominates top of democracy index, North Korea lags in last. Erişim adresi, (12 Şubat 2019): https://www.abc.net.au/news/2019-01-10/democracy-indexeconomist-intelligence-unit-2018/10703184.

Donahue, Patrick. (2019, 16 Ocak). "Merkel rejects Trump claims that German Cars are threat", Bloomberg, Erişim adresi, (20 Mart 2019): https://www.bloomberg.com/news/articles/2019-02-16/merkel-pushesback-on-u-s-claims-that-german-cars-are-a-threat.

Eğitim Reformu Girişimi. (2017). Eğitim izleme raporu (2016-2017). Erişim adresi, (14.02.2019): http://www.egitimreformugirisimi.org/wp-content/uploads/2017/03/EIR2016-17_12.10.17.web-1.pdf.

Esfender, Korkmaz. (2018). Demokrasi ve kalkınmanın şifreleri. İstanbul: Himalaya Yayınları.

Genç, Ömür. (2016). Türkiye ara malı dış ticareti (sektörel analiz). Erişim adresi, (12 Şubat 2019): http://www.kalkinma.com.tr/data/file/raporlar/ESA/ga/2016-GA/Turkiye_Ara_mali_Dis_Ticareti.pdf.

Göncü, Ahmet. (2017)." Çin'in Avrupa Birliği stratejisinden çıarılacak dersler", Anadolu Ajansı. 
Gümrük ve Ticaret Bakanlığı. (2017, 25 Mayıs). Küresel rekabetçilik raporu (2016-2017). Erişim adresi, (14 Şubat http://risk.gtb.gov.tr/data/52c58a61487c8eca94a7c696/Kuresel\%20Rekabet\%C3\%A7ilik\%20Raporu\%202 016-2017\%2025_05_2017.pdf

Han, E. (2004). Kalkınma ve azgelişmişlik. E. Kutlu (Ed.), İktisadi kalkınma ve büyüme içinde (s. 1-24). Eskişehir: Anadolu Üniversitesi.

Harris, Stuart. (2014). Çin Dış Politikası. A.Y.Şir (çev.), İstanbul: Matbuat Yayın Grubu ( Orijinal baskı tarihi 2014).

Hazine ve Maliye Bakanlığı. (2018). Ekonomik göstergeler. Erişim adresi, (30 Ocak 2019): https://www.hmb.gov.tr/ekonomik-gostergeler.

Hinchliffe, Tim. (2016, 29 Haziran). "Big Banking \& Oil : Which country do we invade next after Syria?", The Sociable, Erişim adresi, (20 Mart 2019):https://sociable.co/web/banking-oil-invade-syria-whos-next/.

Huang, Yanzhong ve Ding, Sheng. (2006). Dragon's underbelly: An analysis of China's soft power. East Asia23, no. 4: 22-44

Huntington, Samuel P. (2007). Üçüncü dalga 20. yüzyıl sonlarında demokratlaşma. Ergun Özbudun (Çev.). Ankara: Kita Yayınları.

Ikenberry, John. (2008) "The rise of China and the future of the West", Foreign Affairs, (January/February 2008).

International Monetary Fund. (2018). Canada country data. Erişim adresi, (05 Şubat 2019): https://www.imf.org/en/Countries/CAN\#countrydata.

InvestAZ. (2016, 22 Ekim). Tüketici güven endeksi yatırımları nasıl etkiler? Erişim adresi, (13 Şubat 2019): https://www.investaz.com.tr/blog/tuketici-guven-endeksi-yatirimlari-nasil-etkiler/.

Kaya, E. A. (2004a, Ekim). Ekonomik büyümenin belirleyici ve dişsal büyüme kuramları. E. Kutlu (Ed.), İktisadi kalkınma ve büyüme içinde (s. 263-289). Eskişehir: Anadolu Üniversitesi.

Kaya, E. A. (2004b, Ekim). İçsel büyüme kuramları. E. Kutlu (Ed.), İktisadi kalkınma ve büyüme içinde (s. 291312). Eskişehir: Anadolu Üniversitesi.

Li, Xin, Brødsgaard, Kjeld Eric ve Jacobsen, Michael. (2009) 'Redefining Beijing consensus: ten economic principles, China Economic Journal, 2: 3, 297 -311.

Makine Mühendisleri Odası. (2018). Dünyada ve Türkiye'de ar-ge faaliyetleri. Erişim adresi, (12 Şubat 2019): https://www.mmo.org.tr/sites/default/files/ARGE\%20rapor\%20web.pdf.

Marx, Karl. (1867/2004). Kapital I (çev Alaattin Bilgi), Ankara : Sol Yayınları.

Merkez Bankası. (2018, 29 Aralık). 28.12.2017 günü saat 15:30'da belirlenen gösterge niteliğindeki Türkiye Cumhuriyet Merkez Bankası Kurları. Erişim adresi, (04 Şubat 2019): https://www.tcmb.gov.tr/wps/wcm/connect/TR/TCMB+TR/Main+Menu/Istatistikler/Doviz+Kurlari/Gos terge+Niteligindeki+Merkez+Bankasi+Kurlarii/.

Merkez Bankası. (2017, 29 Aralık). 29.12.2017 günü saat 15:30'da belirlenen gösterge niteliğindeki Türkiye Cumhuriyet Merkez Bankası Kurları. Erişim adresi, (04 Şubat 2019): https://www.tcmb.gov.tr/wps/wcm/connect/TR/TCMB+TR/Main+Menu/Istatistikler/Doviz+Kurlari/Gos terge+Niteligindeki+Merkez+Bankasi+Kurlarii/.

O’Neill, Jim. (2001) Building Better Global Economics BRICs, Global Economics Paper No:66, GoldmanSachs.

Özlü, Faruk. (2018, 30 Mart). 2 bin 600 ithal ürün Türkiye'de üretilecek. Erişim adresi, (12 Şubat 2019): http://ekonomi.haber7.com/ekonomi/haber/2588303-2-bin-600-ithal-urun-turkiyede-uretilecek. 
Ping, Chen. (2009) "From an efficient to a viable international financial market in China's new place in a world in crisis, Ross Garnaut, Ligang Songand Wing Thye Woo (ed.), The Australian National University, ss.1550.

Strange, Suzan. (1988). States and markets -an introduction to international political economy, London.

Sullivan, Kate ve Stark, Liz. (2019, 14 Ocak). Trump threatens to 'devastate' Turkey's economy if they attack Kurds in Syria. Erişim adresi, (01 Şubat 2019): https://edition.cnn.com/2019/01/13/politics/trump-turkeykurds/index.html.

Swaine, Jon. (2018, 13 May1s). "US threatens European Companies with sanctions after Iran deal pullout", The Guardian, Erişim adresi, (20 Mart 2019): https://www.theguardian.com/world/2018/may/13/ussanctions-european-countries-iran-deal-donald-trump.

Şimşek, Mehmet. (2018, 24 Şubat). Mehmet Şimşek cari açık ve borçlanma ile ilgili soruları yanıtladı [Video]. Erişim adresi: https://www.youtube.com/watch?v=bYEqPKHJQM0.

Terzi, Mahir. (2018). "Reconstruction of idealism in theorizing scientifically the discipline of international relations for peace and international security: Idea-realism " . Uluslararası Kriz ve Siyaset Araştırmaları Dergisi, 2 (1), 10-40.

Ticaret Bakanlığı. (2019, Kasım). Ekonomik görünüm. Erişim adresi, (12 Şubat 2019): https://www.ticaret.gov.tr/.

Tokyol, Gonca. (2018, 24 Ekim). Türkiye'nin kredi risk primi, son 1 yılda yüzde 130 arttı. Erişim adresi, (17 Şubat 2019): https://t24.com.tr/haber/turkiyenin-kredi-risk-primi-son-1-yilda-yuzde-130-artti,730966.

Türkiye İstatistik Kurumu. (2019a). Gayrisafi yurtiçi hasıla, iktisadi faaliyet kollarına (A21) göre cari fiyatlarla (değer, pay, değişim oranı). Erişim adresi, (07 Şubat 2019): http://tuik.gov.tr/UstMenu.do?metod=temelist.

Türkiye İstatistik Kurumu. (2019b). Tüketici güven endeksi (arındırılmamış). Erişim adresi, (13 Şubat 2019): http://www.tuik.gov.tr/UstMenu.do?metod=temelist.

Türkiye Odalar ve Borsalar Birliği [TOBB]. (2018). Ekonomik rapor 2017. Erişim adresi, (06 Şubat 2019): https://www.tobb.org.tr/Documents/yayinlar/2018/EkonomikRapor2017.pdf.

Uhlig, Helmut. (2000). İpek yolu Çin ve Roma arasında eski dünya kültürü. A. Kırım (çev.). İstanbul: Okyanus Yayıncilik.

Ulusoy, Veysel. (2019, 2 Ocak). Türkiye ekonomisi krizin hangi aşamasında? 2019'da ekonomiyi neler bekliyor? [Video]. Erişim adresi: https://www.youtube.com/watch?v=70C3wxPC8k4.

Williamson, John. (2004), The Washington consensus as policy prescription for development Delivered at the World Bank on January 13, 2004.

World Bank. (2019a). Services, value added (\% of GDP). Erişim adresi, (05 Şubat 2019): https://data.worldbank.org/indicator/NV.SRV.TOTL.ZS.

World Bank. (2019b). Industry (including construction), value added (\% of GDP). Erişim adresi, (05 Şubat 2019): https://data.worldbank.org/indicator/NV.IND.TOTL.ZS.

World Bank. (2019c). Agriculture, forestry and fishing, value added (\% of GDP). Erişim adresi, (05 Şubat 2019): https://data.worldbank.org/indicator/NV.IND.TOTL.ZS.

World Government Bond. (2019). Turkey credit ratings. Erişim adresi, (17 Şubat 2019): http://www.worldgovernmentbonds.com/credit-rating/turkey/.

World Integration Trade Solution [WITS]. (2019, 07 Şubat). ICT service exports (\% of service exports, BoP). Erişim adresi, (08 Şubat 2019): https://wits.worldbank.org/CountryProfile/en/Country/BYCOUNTRY/StartYear/ 1988/ EndYear/2015/Indicator/BX-GSR-CCIS-ZS. 
World Economic Froum. (2016). The global competitiveness report. Erişim adresi, (14 Şubat 2019): http://www3.weforum.org/docs/GCR2016-2017/05FullReport/TheGlobal CompetitivenessReport20162017_FINAL.pdf.

Yenipazarll, A., Bulut, E. ve Kavak, G. "Seçilmiş ülke ve ülke gruplarında kredi derecelerinin yatırımlar üzerine etkisi". Aydın İktisat Fakültesi Dergisi, 2(1), 80-104.

Yerasimos, Stefanos. (2001). Azgelişmişlik sürecinde Türkiye (Cilt 1,2). Babür Kuzucu (Çev.). İstanbul: Belge Yayınları.

\section{Açıklamalar}

1. Türkiye'nin terörle mücadelesi ile ülke ve sınır güvenliğini korumak amacıyla giriştiği sınır ötesi harekâtlar, uluslararası hukukun cevaz verdiği karşlıklardır. Fethullahçı Terör Örgütü (FETÖ)'nün Türkiye'nin imajina verdiği zarar da göz ardı edilemez bir gerçektir ve Türkiye hala bunun yaralarını sarmakla meşgul olduğu gibi bir yandan da tahrifatın derinlerine inmeye, bunları tespit etmeye çalışmaktadır. Böyle dönemler de taraflar arasındaki tezat argümanlar arasında kaybolmak da mümkündür. Ancak, değerlendirmede kıstas olarak değerler dikkate alınırsa ve dikkate alınan bu değerlerin özüne yani ruhuna göre kritik yapılırsa, sağduyu, kişiyi daha sağlıklı yorumlara götürebilecektir. Haliyle bu çerçevede düstur, "iyi bir demokrasi nasıl olmalıdır" şeklinde ortaya konabilir.

2. Huntington'ın (2007) tespitiyle, demokrasi dalgaları açısından, ekonomik ilerlemenin beraberinde demokrasiyi getireceği çıkarımından hareketle, Çin'in de ekonomik başarısının ardından siyasal liberalizmi talep edecek bir kamuoyuna sahip olması beklenebilir mi? Yoksa Çin, nevi şahsına münhasır bir örnek olarak mı kalacak, bunu zaman gösterecektir.

3. Krizler döviz, borç krizi, petrol sıkıntısı olarak ortaya çıkabilir. Bu krizlere örnek olarak 1929 Dünya Büyük Buhranı, 1970 Petrol krizi, 1994 Meksika- 1997 Asya Krizi -1998 Rusya-1999 Brezilya -2001 Arjantin ve Türkiye2007 ABD ve 2009 AB mali krizleri verilebilir.

4. Öncelikle işçi grevleri ile başlayan, sonrasında eşit hizmet için halk hareketleri, yasa dışı arazi ve ev işgalleri, öğrenci ve gençlik hareketleri, çevresel adalet mücadeleleri devlet iktidarını ele geçirmeye yönelik siyasi hareketlere dönüşebilmektedir. Büyük bir devlet de iktidarını değiştirmek istediği ülkelere yönelik bu tarz ekonomik sorunları derinleştirici politikaları hayata geçirebilmektedir.

5. John Williamson tarafından ilk kez 1989'da kullanılan Washington Uzlaşısı kavramı, Washington merkezli IMF ve Dünya Bankası önderliğinde 10 madde olarak; mali disiplin, kamu harcamalarının yeniden düzenlenmesi, vergi reformu, finansal serbestleşme, rekabetçi döviz kuru politikaları, ticari serbestleşmenin önündeki engellerin kalkması, doğrudan yabancı yatırımların önünü açacak düzenlemeler ve özelleştirme politikaları, piyasaları denetleyecek ve düzenleyecek kurumların devre dışı bırakılması ve bağımsız üst düzenleyici kurullar maskesi altında düzenlenme karşılığı ve mülkiyet haklarına sınırsız güvenceler olarak adlandırılmaktadır. (Williamson, 2004, ss. 13-14)

6. Stratejik endüstri alanlarına yoğunlaşma. Sermaye yoğun, bilgi yoğun ve yüksek teknoloji öncelikli sanayi alanları kast edilmiştir. Yüksek teknolojili ürünlerin ihracat artısııı sağlamada katkısı büyük olmaktadır.

7. Ticari devlet ilkesi öncelikle, duygulardan çok rasyonel hareket etmeyi ön plana çıkarmaktadır. Sanayi 4.0 ve üretimde robot teknolojisi işgücü piyasalarını değiştirecektir. Ancak ticaret önem kazanacaktır. Akdeniz ve Ege ‘de stratejik limanlara, yaşanılan ekonomik krizi fırsata çeviren Çin yerleşmeye başlamıştır. Yunanistan ve İtalya ve hatta İsrail Hayfa limanlarının işletmelerini almıştır. 2. İpek Yolu projesi, ABD dışında tüm dünyayı Çin merkezinin etrafına bağlamaktadır. Dünya gelişmeleri sonucu çok yönlü işbirliğine dayalı adil bir ekonomik düzen yaratılması Türkiye'nin de çıkarına olacaktır.

8. Bu konuda bir açıklama için bakınız Memduh Bayraktaroğlu (2018).

9. Bu konuda bir açılama için bakınız Veysel Ulusoy (2019). 
10. Bu konuda bir açıklama için bakınız Ekonomiden Sorumlu Başbakan Yardımcısı Mehmet Şimşek (2018).

11. Cumhuriyet Öncesi döneme yönelik mükemmel bir çalışma için bakınız Stefanos Yerasimos (2001).

12. Veriler, Hazine ve Maliye Bakanlığı ile Merkez Bankası'ndan derlenmiştir.

13. Veriler Hazine ve Maliye Bakanlığı ile International Monetary Fund (IMF)'den derlenmiştir.

14. Bu konuda, inşaat sektörü için yanlı büyüme tartışmasını hatırlamak yerinde olacaktır. Yanlı büyüme tartışması için bakınız Ulusoy (2019). İnşaat sektörü, Türkiye'nin gayri safi yurtiçi hasılasında 2017 yılı itibariyle nominal rakamlar üzerinden yüzde 7,6, cari yani enflasyon etkisine göre belirlenen rakamlar üzerinden ise yüzde 8,6 paya sahiptir. Oranlar için bakınız Hazine ve Maliye Bakanlığ (2018). Öte taraftan inşaat sektörü ekonominin önemli sektörlerinden biri olarak görülmektedir. İnşaat sektörüne ilişkin açıklamalar için bakınız Türkiye Odalar ve Borsalar Birliği (2018, ss. 52-54). Diğer bir ifadeyle, inşaat sektörü bir yandan yanlı büyüme olarak kritize edilirken, öte taraftan diğer sektörleri de canlandırdığ için ekonomide önemli bir sektör olarak görülebilir. Ancak iktisat, aynı zamanda, mevcut imkânlar ve kapasite çerçevesinde bir tercih yapma meselesidir ve bu kaçınılmaz gözükmektedir.

15. Bununla birlikte Samuel Huntington'a göre ekonomi ile demokrasi arasındaki ilişkide, ekonomi, bağımsız değişken olarak durmaktadır. Üçüncü Dalga adlı kitabında, 1974-1989 yılları arasında demokratlaşan ülkeleri incelediğinde, ekonomik gelişme ve demokrasi arasındaki ilişkiye temas etmiş ve yoksulluğun demokrasiye engel olduğu sonucuna varmıştır. Ayrıntı için bakınız Huntington (2007, ss. 327-333).

16. Avrupa Birliği'ne aday ülke olarak kırmızı çizgileri aştığı ileri sürülen Türkiye'nin katılım müzakerelerinin askıya alınması gerektiğini söyleyen Avrupa Parlamentosu Dış İlişkiler Komitesi, Türkiye'de demokratik denetim eksikliği olduğunu, Türkiye'nin demokratik reformlara geri dönmesi ve yargı bağımsızlığını sağlaması gerektiği belirtmektedir. Ayrıntı için bakınız Özkan (2019).

17. 0 ile 200 arasında değer alan tüketici güven endeksinde, şayet endeks değeri 100'ün üstündeyse, ülke ekonomisinin gidişatı olumlu olarak yorumlanır ve bu da ülke ekonomisinin büyüyor olmasının göstergesidir. Değer olarak 100'ün altında ise durum ekonomide küçülmeyi ifade eder (InvestAZ, 2016).

18. Veriler, 2012 yılına aittir ve listenin tamamı için bakınız Genç (2016, s. 9).

19. Tespit edilen 2.600 farklı ithal ara malı ürününün, Türkiye'nin kendi kaynaklarıyla üretilmek istendiğine ilişkin dönemin Bilim, Sanayi ve Teknoloji Bakanı Faruk Özlü’nün açıklaması için bakınız Özlü (2018).

20. 181 ülkeye (veya tanımlı konuma) ilişkin 1988-2015 yılları verileri için bakınız: https://wits.worldbank.org/CountryProfile/en/Country/BY-COUNTRY/StartYear/1988/EndYear/2015/Indicator/ BX-GSR-CCIS-ZS.

21. Büyüme, nitelikten ziyade nicelikle ilgili olup, üretimin ve kişi başına gelirin reel olarak artırılmasıdır. Kalkınma ise salt anlamda üretimin ve kişi başına gelirin artırılması olmayıp, azgelişmiş bir toplumda iktisadi ve sosyokültürel yapının da değiştirilmesi, yenileştirilmesidir. Kalkınma "insanlık adına toplumun yüksek kültür ürünlerini üretebilmesi için gerçekleştirmesi gereken b,r süreç ve sürekli bir yarıştır”. Ayrıntı için bakınız Han (2004, ss. 3-5).

22. Yüksek teknoloji ürün ihracatı ile küresel doğrudan yabancı sermaye yatırımı arasındaki doğru orantılı ilişki için bakınız Akkaya (2019, ss. 283-303).

23..Din eğitimi ile ilgili bir değerlendirme için bakınız Eğitim Reformu Girişimi (2018, ss. 93-94). 